\title{
Development of 'Lignin-First' Approaches for the Valorization of Lignocellulosic Biomass
}

\author{
Tamás I. Korányi ${ }^{1, * \mathbb{D}}$, Bálint Fridrich ${ }^{2}$, Antonio Pineda ${ }^{3}$ and Katalin Barta ${ }^{2,4}$ \\ 1 Surface Chemistry and Catalysis Department, Centre for Energy Research, Konkoly Thege M. u. 29-33, \\ 1121 Budapest, Hungary \\ 2 Stratingh Institute for Chemistry, University of Groningen, Nijenborgh 4, \\ 9747 AG Groningen, The Netherlands; b.fridrich@rug.nl (B.F.); k.barta@rug.nl (K.B.) \\ 3 Department of Organic Chemistry, University of Cordoba, Ed. Marie Curie (C 3), Campus of Rabanales, \\ Ctra Nnal IV-A, Km 396, E14014 Cordoba, Spain; q82pipia@uco.es \\ 4 Department of Chemistry, Organic and Bioorganic Chemistry, University of Graz, Heinrichstrasse 28/II, \\ 8010 Graz, Austria \\ * Correspondence: koranyi.tamas@energia.mta.hu
}

Academic Editors: Alejandro Rodríguez and Eduardo Espinosa

check for Received: 27 May 2020; Accepted: 14 June 2020; Published: 18 June 2020

\begin{abstract}
Currently, valorization of lignocellulosic biomass almost exclusively focuses on the production of pulp, paper, and bioethanol from its holocellulose constituent, while the remaining lignin part that comprises the highest carbon content, is burned and treated as waste. Lignin has a complex structure built up from propylphenolic subunits; therefore, its valorization to value-added products (aromatics, phenolics, biogasoline, etc.) is highly desirable. However, during the pulping processes, the original structure of native lignin changes to technical lignin. Due to this extensive structural modification, involving the cleavage of the $\beta-\mathrm{O}-4$ moieties and the formation of recalcitrant $\mathrm{C}-\mathrm{C}$ bonds, its catalytic depolymerization requires harsh reaction conditions. In order to apply mild conditions and to gain fewer and uniform products, a new strategy has emerged in the past few years, named 'lignin-first' or 'reductive catalytic fractionation' (RCF). This signifies lignin disassembly prior to carbohydrate valorization. The aim of the present work is to follow historically, year-by-year, the development of 'lignin-first' approach. A compact summary of reached achievements, future perspectives and remaining challenges is also given at the end of the review.
\end{abstract}

Keywords: lignocellulose valorization; 'lignin-first'; reductive catalytic fractionation

\section{Introduction}

Plant cells' composite material is lignocellulose, which mainly consists of cellulose, hemicellulose, and lignin and in total accounts for ca. $90 \%$ of dry matter of land-based biomass. Depending on its origin, lignocellulose can be divided into three main categories-i.e., softwood, hardwood, and grass. In fact, the lignin content is highest in softwood, followed by hardwood and lowest in grasses [1,2].

Cellulose and hemicellulose are both polysaccharides, differing in building units, degree of polymerization and morphology. Lignin is a complex aromatic biopolymer built up from three monolignols: p-coumaryl alcohol, coniferyl alcohol, sinapyl alcohol (Figure 1). These monolignols differ in the number of methoxy groups (none, one, and two) attached to the aromatic ring and make up the three key lignin units (H (hydroxyphenyl), $\mathrm{G}$ (guaiacyl), and S (syringyl), respectively). G units constitute approximately $90-95 \%$ of softwood lignin, whereas $25-50 \%$ of $G$ and $50-75 \%$ of $S$ units are typically found in hardwood lignin. Because the coupling of the monolignols is a process involving radicals, there are many possible linkages between the sub-units, involving different $\mathrm{C}-\mathrm{C}$ and $\mathrm{C}-\mathrm{O}$ bonds with certain linkages being more prevalent than others. A typical linkage in both softwood 
and hardwood lignins is the $\beta-\mathrm{O}-4$ ether bond (Figure 1 ), approximately reaching half of the lignin in softwood and more than $60 \%$ in hardwood. Hardwood lignin contains less C-C linkages than softwood, because the additional methoxy groups on the aromatic rings, mainly in the $S$ units, prevent their formation [1,2].

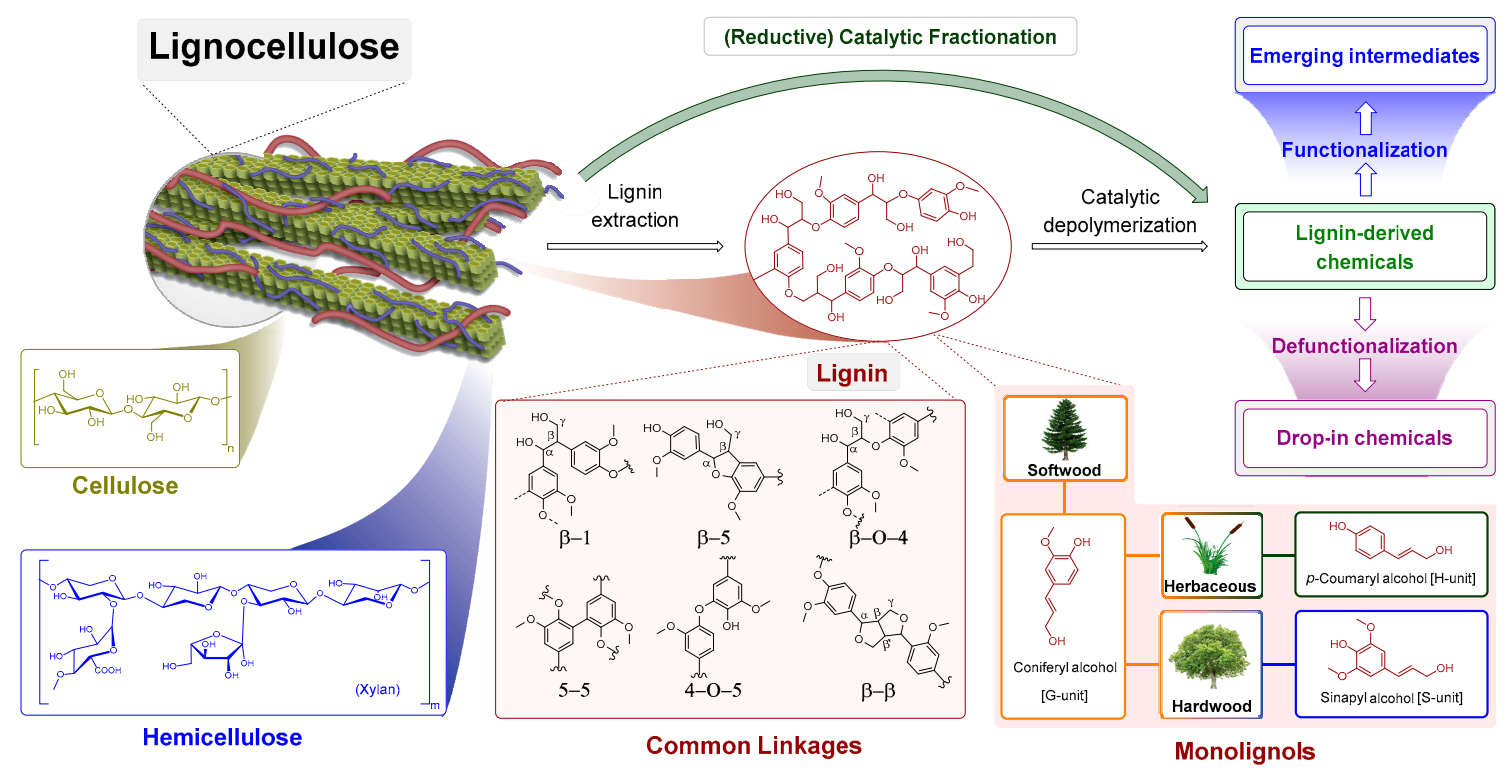

Figure 1. General strategies for lignocellulose valorization and application of lignin-derived platform chemicals with representative lignin structure displaying typical lignin subunits and linkages.

Currently, only the cellulosic part of lignocellulosic biomass is used effectively as feedstock for the pulp and paper industry and as precursor of second-generation bioethanol. Traditionally, lignin is isolated from lignocellulosic biomass by fractionation in the pulp and paper industry (route $a$ in Figure 2) and by fermentation in biorefineries producing cellulosic ethanol (route $\boldsymbol{b}$ in Figure 2). Pulping methods result in structurally heavily modified lignins (route $\boldsymbol{a}$ in Figure 2), while enzymatic lignin displays mild structural modification (route $\boldsymbol{b}$ in Figure 2) [3]. The chemical structure of native lignin is altered during conventional lignocellulose fractionation methods: ether bonds $(\beta-\mathrm{O}-4$ and 4-O-5 in Figure 1) are cleaved and new stable C-C linkages are formed, resulting in more condensed and unreactive technical lignins [4]. Therefore, essentially under pulping conditions lignin undergoes structural rearrangement leading to the formation of unnatural C-C bonds [5]. High-yield lignin depolymerization methods are limited by the presence of these linkages formed during lignin extraction as well as the interunit carbon-carbon bonds within native lignin [6].

Several methods have investigated the catalytic conversion of recalcitrant lignins obtained from the pulp and paper industry, generally requiring harsher reaction conditions in order to achieve feasible product yields [2,3,5,7-9]. On the other hand, lignins obtained upon milder enzymatic digestion would lead to higher aromatic monomer yields, after catalytic depolymerization [1,10,11]. Many studies focusing on catalyst development for lignin depolymerization have used organosolv lignins prepared in the respective laboratories, using different fractionation procedures, which in terms of severity would fall between the industrial pulping conditions and enzymatic digestion $[2,3,5,7]$. Lignin valorization leads to value-added products such as biofuels, macromolecules (carbon fiber, polyurethane) and aromatics (BTX, monophenolic compounds) [12]. Functionalized lignin monomers can be regarded as perspective lignin-derived platform chemicals, from which emerging intermediates can be produced leading to pharmaceuticals, fine chemicals, polymers, and fuels. The other groups are drop-in chemicals with an existing market platform leading to bulk chemicals (Figure 1) [13]. 


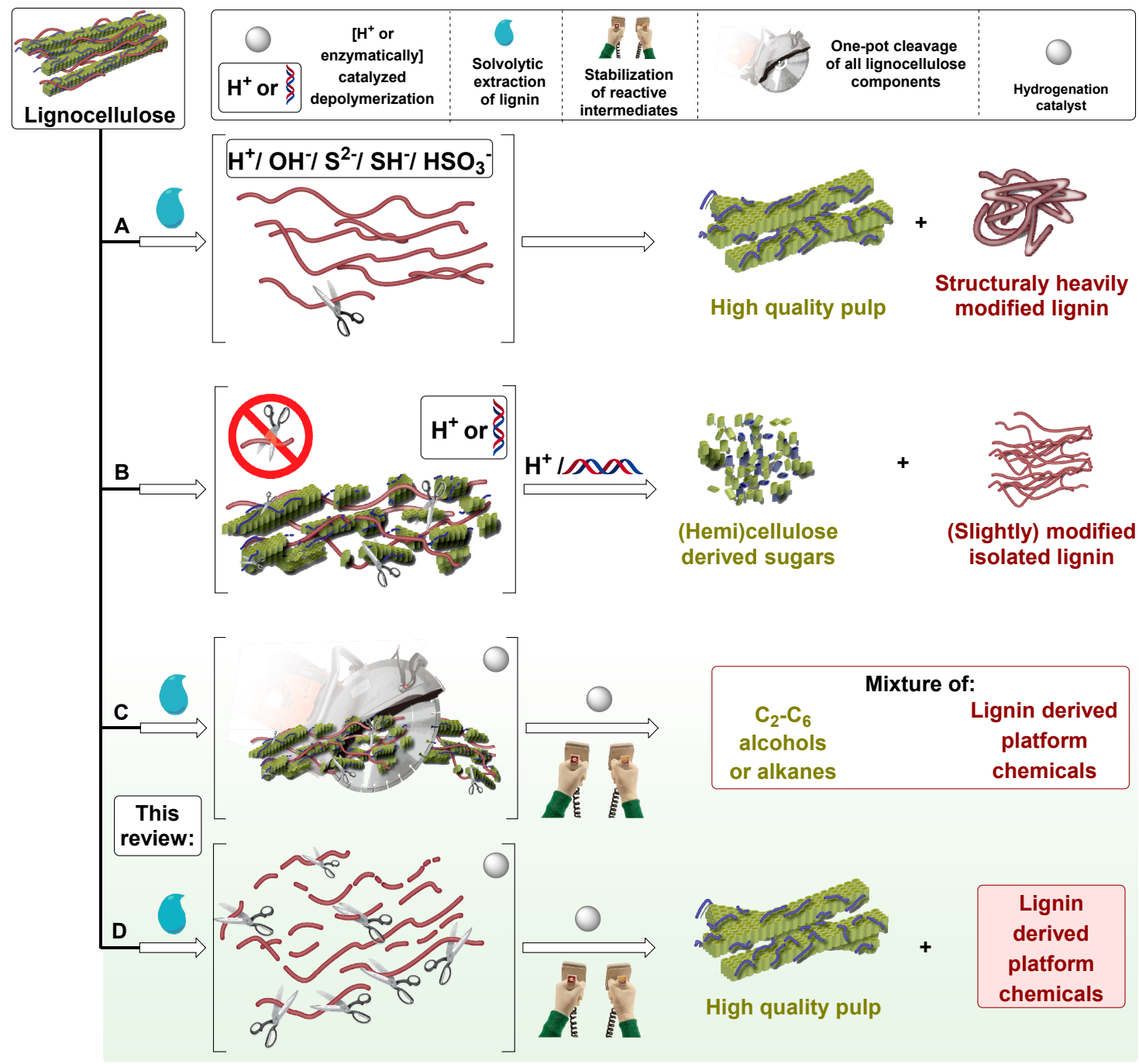

Figure 2. Types of lignocellulose valorization processes. (A) Harsh (pulping) fractionation. (B) Mild (enzymatic) fractionation. (C) One-step reductive catalytic processing. (D) Reductive catalytic fractionation (RCF).

Other approaches that emerged for the valorization of the whole lignocellulose are methods, which allow for the catalytic conversion of all constituents of lignocellulose, simultaneously. During these processes, product mixtures of cellulose as well as lignin are generated. For example, complete conversion of all lignocellulose components to lignin monomers and $\mathrm{C}_{2}-\mathrm{C}_{6}$ alcohols and/or alkanes is also possible by one-step reductive catalytic processing (route $c$ in Figure 2) $[3,13]$.

A method that emerged as alternative to lignin valorization is the so-called 'lignin-first' process. Already, several excellent reviews have discussed this powerful strategy [3,5,14-20]. Dubbed 'lignin-first', this approach considers the catalytic conversion of lignin during biomass fractionation, in other words solvolytic extraction of lignin accompanied by instant lignin depolymerization and predominantly reductive stabilization of reactive intermediates (route $\boldsymbol{d}$ in Figure 2) [4]. This approach is also called 'early-stage catalytic conversion of lignin' (ECCL) [14] or, when using a metal catalyst under reductive atmosphere, as 'reductive catalytic fractionation' (RCF) [15]. The extraction and immediate catalytic conversion of lignin to monomers by these methods from lignocellulose directly in the presence of a catalyst, usually under reductive conditions, results in higher yield of aromatic monomers due to the higher presence of cleavable C-O linkages and less C-C linkages [3]. RCF is also a two-step process, extracting lignin from whole biomass with a polar-protic solvent, and then selectively cleaving $\mathrm{C}-\mathrm{O}$ ether bonds using a hydrogen donor and a heterogeneous catalyst. As a 
result, the process yields a depolymerized lignin oil rich in phenolic monomers, dimers, and oligomers, next to a solid carbohydrate pulp, which is amenable to further valorization. The most common solvents are alcohols (mainly methanol) and water/organic solvent mixtures such as water/dioxane and water/ethanol. The hydrogen donor can be pressurized hydrogen gas or can originate from the solvent or from the lignocellulose itself [16]. Generally, nickel or noble metal catalysts are used.

Different pathways and mechanisms have been proposed for the RCF process. The key steps in all cases are solvolysis as well as hydrogenolysis of ether bonds, removal of benzylic OH-groups $\left(\mathrm{OH}_{\alpha}\right)$, and possible removal of $\mathrm{OH}_{\gamma}$-groups. These primary reactions lead to the formation of substituted methoxyphenols and small oligomeric fragments. Additional hydrogenation of alkenyl and carbonyl groups, as well as hydrogenolysis, can take place (secondary reactions) [14,16,21].

A detailed overview of RCF processes is presented in Figure 3 and discussed fully in the paper of Rinaldi et al. [21]. The lignin fragments present in the liquor are prone to several types of reaction. Under pulping conditions lignin fragments undergo recondensation, into technical lignins containing strong C-C bonds [14]. The main difference between pulping (route $\boldsymbol{a}$ in Figure 2) and these processes (routes $c$ and $d$ in Figure 2), is that in the latter two, catalytic processing of lignin happens in its native form in conjunction with fractionation, or parallel to cellulose processing. Under these conditions, reactive fragments or intermediates that originate during pulping immediately undergo stabilization (typically by hydrogenation see Figure 3) to form more stable molecules. Possible lignin-derived monomers obtained thus far from routes $c$ and $d$ combined (Figure 2) are collected in Figure 4.

\begin{tabular}{|l|}
\hline Species dissolved in the liquor: \\
- Recondensation of lignin oligomers \\
- Cross condensation of lignin and \\
sugar degradation products \\
- Degradation of lignin oligomers \\
(e.g. elimination of $\gamma$ - $\mathrm{CH}_{2} \mathrm{OH}$ group \\
as formaldehyde) \\
- Degradation of $\mathrm{C}_{5}$ and \\
$\mathrm{C}_{6}$ hemicellulose sugars \\
\hline Lignocellulosic matrix: \\
Processes on lignin: \\
- Solvolysis of $\beta$-ethers \\
- Release of lignin oligomers \\
- Recondensation of lignin oligomers \\
- Redeposition of lignin \\
via recondensation \\
Processes on hemicellulose: \\
- Deacetylation \\
- Solvolysis / Hydrolysis \\
- Release of $\mathrm{C}_{5}$ and $\mathrm{C}_{6}$ sugars \\
- Condensation of degradation products \\
forming pseudolignins (humins)
\end{tabular}

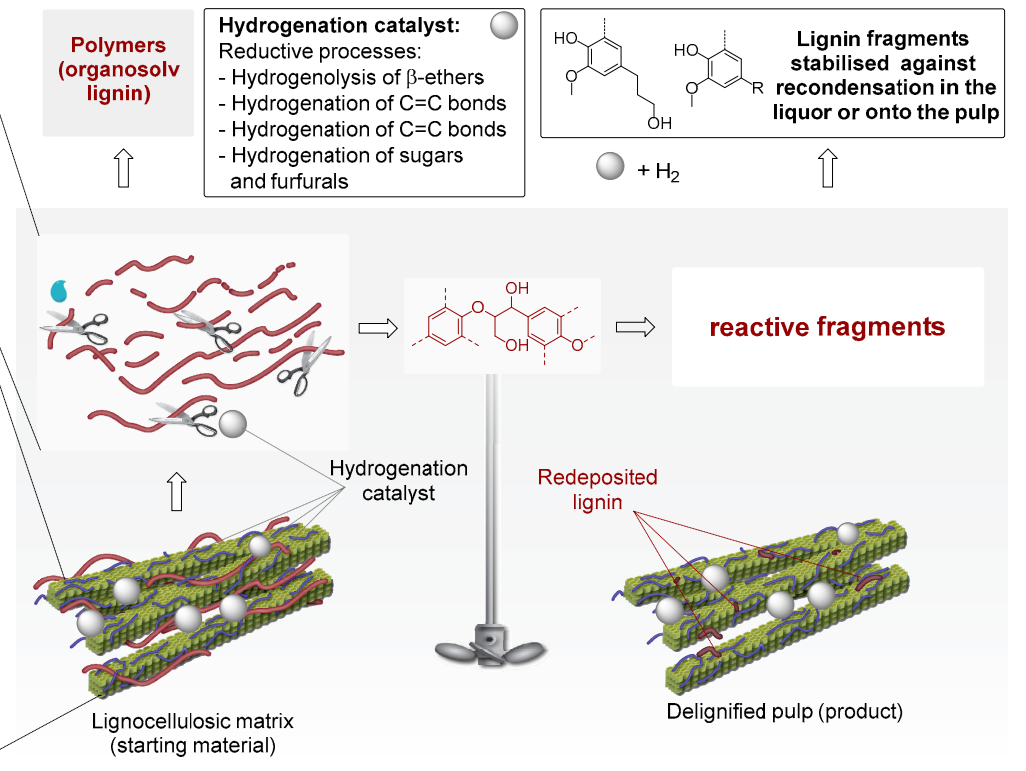

Figure 3. Schematic representation of chemical processes involved in the 'lignin-first' biorefining. For clarity, hemicellulose sugars and their degradation products were omitted.

The aim of this review is to follow historically the development of 'lignin-first' approach with inclusion of one-pot reductive catalytic depolymerization of all lignocellulosic components in the scientific literature. The number of these publications has increased significantly in the past years, new ideas emerged, and some novel methods were developed. 
Table 1. 'Lignin-first' or reductive catalytic fractionation (RCF) papers in the literature.

\begin{tabular}{|c|c|c|c|c|c|c|c|c|c|c|}
\hline \multirow[t]{2}{*}{ Entry } & \multirow[t]{2}{*}{ Year } & \multirow[t]{2}{*}{ Feedstock } & \multirow[t]{2}{*}{ Catalyst } & \multirow[t]{2}{*}{ Solvent } & \multicolumn{3}{|c|}{ Reaction Conditions } & \multirow{2}{*}{$\begin{array}{l}\text { Yield of Main Products } \\
\text { wt \% }\end{array}$} & \multirow{2}{*}{$\begin{array}{l}\text { Lignin Monomer } \\
\text { Yield (wt \%) }\end{array}$} & \multirow[t]{2}{*}{ Reference } \\
\hline & & & & & $\mathrm{T}\left({ }^{\circ} \mathrm{C}\right)$ & $\mathrm{p}(\mathrm{bar})$ & $\mathrm{t}(\mathrm{h})$ & & & \\
\hline 1 & 1940 & maple, spruce & $\mathrm{Cu}_{2} \mathrm{Cr}_{2} \mathrm{O}_{5}$ & dioxane & 250 & $333\left(\mathrm{H}_{2}\right)$ & 12 & 4-propylcyclohexanol, 4-propylcyclohexanediol & & [22] \\
\hline 2 & 1941 & maple, spruce & $\mathrm{Cu}_{2} \mathrm{Cr}_{2} \mathrm{O}_{5}$ & dioxane & 280 & $\mathrm{H}_{2}$ & 10 & 4-propylcyclohexanol & 36 & [23] \\
\hline 3 & 1943 & maple & $\mathrm{Cu}_{2} \mathrm{Cr}_{2} \mathrm{O}_{5}$ & dioxane & 280 & $\mathrm{H}_{2}$ & 20 & 4-propylcyclohexanol, 3-cyclohexyl-1-propanol & 40 & [24] \\
\hline 4 & 1948 & maple & Raney-Ni $+\mathrm{NaOH}$ & dioxane $/ \mathrm{H}_{2} \mathrm{O}(1: 1)$ & 173 & $210\left(\mathrm{H}_{2}\right)$ & 6 & $15 \%$ 4-ethylsyringol, $6 \%$ 4-ethanolsyringol & 27 & [25] \\
\hline 5 & 1963 & aspen & Raney-Ni & dioxane $/ \mathrm{H}_{2} \mathrm{O}(1: 1)$ & 220 & $35\left(\mathrm{H}_{2}\right)$ & 5 & $29 \%$ 4-propylsyringol, $13 \%$ 4-propanolsyringol & 59 & [26] \\
\hline 6 & 1966 & spruce & $\mathrm{Pd} / \mathrm{C}$ & dioxane $/ \mathrm{H}_{2} \mathrm{O}(1: 1)$ & 195 & $35\left(\mathrm{H}_{2}\right)$ & 10 & $17 \%$ 4-propanolguaiacol & 17 & [27] \\
\hline 7 & 1969 & spruce & $\mathrm{Rh} / \mathrm{C}$ & dioxane $/ \mathrm{H}_{2} \mathrm{O}(1: 1)$ & 195 & $35\left(\mathrm{H}_{2}\right)$ & 5 & 11\% 4-propanolguaiacol & 34 & [28] \\
\hline 8 & 1970 & spruce & Raney-Ni & dioxane $/ \mathrm{H}_{2} \mathrm{O}(1: 1)$ & 195 & $35\left(\mathrm{H}_{2}\right)$ & 5 & $17 \% 4$-propanol-cyclohexanol & 17 & [29] \\
\hline 9 & 1978 & aspen & $\mathrm{Rh} / \mathrm{C}$ & dioxane $/ \mathrm{H}_{2} \mathrm{O}(1: 1)$ & 195 & $34\left(\mathrm{H}_{2}\right)$ & 5 & 26\% 4-propanolsyringol, 13\% 4-propylsyringol & 50 & [30] \\
\hline 10 & 1978 & spruce & $\mathrm{Rh} / \mathrm{C}$ & dioxane $/ \mathrm{H}_{2} \mathrm{O}(1: 1)$ & 195 & $35\left(\mathrm{H}_{2}\right)$ & 5 & $21 \% 4$-propanolguaiacol & 21 & [31] \\
\hline 11 & 1986 & aspen poplar & $\mathrm{Rh} / \mathrm{C}$ & dioxane $/ \mathrm{H}_{2} \mathrm{O}(1: 1)$ & 195 & $35\left(\mathrm{H}_{2}\right)$ & 5 & 21\% 4-propanolguaiacol & 21 & [32] \\
\hline 12 & 1993 & rice husks & polyvalent metals & dioxane & 250 & $50\left(\mathrm{H}_{2}\right)$ & 2 & $33 \% 4$-propylsyringol & 33 & [33] \\
\hline 13 & 2008 & birch & $\mathrm{H}_{3} \mathrm{PO}_{4}+\mathrm{Pt} / \mathrm{C}$ & dioxane $/ \mathrm{H}_{2} \mathrm{O}(1: 1)$ & 200 & $40\left(\mathrm{H}_{2}\right)$ & 4 & $21 \%$ 4-propylsyringol, $15 \%$ 4-propanolsyringol & 46 & [34] \\
\hline 14 & 2011 & pine & $\mathrm{Pd} / \mathrm{C}$ & dioxane $/ \mathrm{H}_{2} \mathrm{O}(1: 1)$ & 195 & $35\left(\mathrm{H}_{2}\right)$ & 24 & $21 \% 4$-propanolguaiacol & 22 & [35] \\
\hline 15 & 2012 & birch & $\mathrm{Ni}-\mathrm{W}_{2} \mathrm{C} / \mathrm{C}$ & ethylene glycol & 235 & $60\left(\mathrm{H}_{2}\right)$ & 4 & $18 \%$ 4-propylsyringol, $10 \%$ 4-propanolsyringol & 47 & [36] \\
\hline 16 & 2013 & birch & $\mathrm{Ni} / \mathrm{C}$ & $\mathrm{MeOH}$ & 200 & $1(\mathrm{Ar})$ & 6 & 36\% 4-propylsyringol, $12 \%$ 4-propylguaiacol & 54 & [37] \\
\hline 17 & 2014 & birch & $\mathrm{Pd} / \mathrm{C}$ & $\mathrm{EtOH} / \mathrm{H}_{2} \mathrm{O}(1: 1)$ & 195 & $4(\mathrm{Ar})$ & 1 & 49\% 4-propenylsyringol & 49 & [38] \\
\hline 18 & 2014 & poplar & Raney-Ni & $2-\mathrm{PrOH} / \mathrm{H}_{2} \mathrm{O}(7: 3)$ & 180 & autogenous & 3 & 4-propanolsyringol & 25 & [39] \\
\hline 19 & 2015 & poplar & $\mathrm{Zn}-\mathrm{Pd} / \mathrm{C}$ & $\mathrm{MeOH}$ & 225 & $35\left(\mathrm{H}_{2}\right)$ & 12 & 30\% 4-propylsyringol, 24\% 4-propylguaiacol & 54 & [40] \\
\hline 20 & 2015 & birch & $\mathrm{Ru} / \mathrm{C}$ & $\mathrm{MeOH}$ & 250 & $30\left(\mathrm{H}_{2}\right)$ & 6 & $31 \%$ 4-propylsyringol, $10 \%$ 4-propylguaiacol & 52 & [41] \\
\hline 21 & 2015 & lignocellulose & $\mathrm{Ru} / \mathrm{C}+\mathrm{H}_{4} \mathrm{SiW}_{12} \mathrm{O}_{40}$ & org.phase $/ \mathrm{H}_{2} \mathrm{O}$ & $140-300$ & $50\left(\mathrm{H}_{2}\right)$ & $<24$ & n-hexane, cyclohexane, methylcyclopentane & $82 *$ & [42] \\
\hline 22 & 2015 & corn stalk & $\mathrm{Ru} / \mathrm{C}+\mathrm{LiTaMoO}_{6}$ & $\mathrm{H}_{3} \mathrm{PO}_{4}$ & 230 & $60\left(\mathrm{H}_{2}\right)$ & 24 & 6\% 4-ethylphenol & 24 & [43] \\
\hline 23 & 2015 & birch & $\mathrm{Pd} / \mathrm{C}$ & $\mathrm{MeOH}$ & 250 & $30\left(\mathrm{H}_{2}\right)$ & 3 & $35 \%$ propanolsyringol, $10 \%$ propanolguaiacol & 49 & [44] \\
\hline 24 & 2015 & birch & $\mathrm{Pd} / \mathrm{C}$ & ethylene glycol & 250 & $30\left(\mathrm{H}_{2}\right)$ & 3 & $35 \%$ propanolsyringol, $12 \%$ propanolguaiacol & 50 & [45] \\
\hline 25 & 2015 & birch & $\mathrm{Ni} / \mathrm{C}$ & $\mathrm{MeOH}$ & 200 & $2\left(\mathrm{~N}_{2}\right)$ & 6 & $18 \% 4$-propylsyringol, $10 \%$ 4-propylguaiacol & 32 & [46] \\
\hline 26 & 2015 & cedar & $\mathrm{H}_{2} \mathrm{SO}_{4}$ & toluene/MeOH & 170 & 1 (air) & 0.1 & $5 \%$ homovanillyl aldehyde dimethyl acetal & 10 & [47] \\
\hline 27 & 2016 & poplar & $\mathrm{Ru} / \mathrm{C}$ & $\mathrm{MeOH}$ & 250 & $40\left(\mathrm{H}_{2}\right)$ & 15 & $49 \%$ propylsyringol, $22 \%$ propanolsyringol & $78^{*}$ & [6] \\
\hline 28 & 2016 & birch & $\mathrm{Pd} / \mathrm{C}$ & $\mathrm{EtOH} / \mathrm{H}_{2} \mathrm{O}(1: 1)$ & 210 & $1(\mathrm{Ar})$ & 15 & $20 \%$ 4-propylsyringol, $11 \%$ 4-propenylsyringol & 36 & [48] \\
\hline 29 & 2016 & poplar & $\mathrm{Zn}-\mathrm{Pd} / \mathrm{C}$ & $\mathrm{MeOH}$ & 225 & $35\left(\mathrm{H}_{2}\right)$ & 12 & 28\% 4-propylsyringol, $14 \%$ 4-propylguaiacol & 43 & [49] \\
\hline 30 & 2016 & miscanthus & $\mathrm{Ni} / \mathrm{C}$ & $\mathrm{MeOH}$ & 225 & $60\left(\mathrm{H}_{2}\right)$ & 12 & $19 \%$ 4-propylsyringol, $21 \%$ 4-propylguaiacol & 68 & [50] \\
\hline 31 & 2016 & poplar & $(\mathrm{Rh}(\operatorname{cod}) \mathrm{Cl})_{2}+\mathrm{Sc}(\mathrm{OTf})_{3}$ & Dioxane $/ \mathrm{H}_{2} \mathrm{O}$ & 175 & & 2 & 3\% 4-propenylsyringol, $2 \%$ 4-methylguaiacol & 10 & [51] \\
\hline 32 & 2016 & birch & $\mathrm{Pd} / \mathrm{C}+\mathrm{Yb}(\mathrm{OTf})_{3}$ & $\mathrm{MeOH}$ & 200 & $30\left(\mathrm{H}_{2}\right)$ & 2 & 4-propanolsyringol, 4-propanolguaiacol & 48 & [52] \\
\hline 33 & 2016 & beech & $\mathrm{Ni} / \mathrm{C}$ & $\mathrm{MeOH} / \mathrm{H}_{2} \mathrm{O}(3: 2)$ & 200 & $60\left(\mathrm{H}_{2}\right)$ & 5 & 29\% 4-propanolsyringol, $10 \% 4$-propanolguaiacol & 51 & [53] \\
\hline 34 & 2016 & corn stover & $\mathrm{H}_{3} \mathrm{PO}_{4}+\mathrm{Ni} / \mathrm{C}$ & $\mathrm{MeOH}$ & 200 & $30\left(\mathrm{H}_{2}\right)$ & 6 & $15 \%$ methyl coumarate, $15 \%$ methyl ferulate & 38 & [54] \\
\hline 35 & 2016 & poplar & $\mathrm{H}_{3} \mathrm{PO}_{4}+\mathrm{Pd} / \mathrm{C}$ & $\mathrm{MeOH}$ & 200 & $20\left(\mathrm{H}_{2}\right)$ & 3 & 21\% 4-propanolsyringol, 14\% 4-propanolguaiacol & 42 & [55] \\
\hline 36 & 2016 & poplar & $\mathrm{Pd} / \mathrm{C}$ & $\mathrm{MeOH} / \mathrm{H}_{2} \mathrm{O}(7: 3)$ & 200 & $20\left(\mathrm{H}_{2}\right)$ & 3 & 23\% 4-propanolsyringol, 13\% 4-propanolguaiacol & 44 & [56] \\
\hline 37 & 2017 & birch & $\mathrm{Pd} / \mathrm{C}+\mathrm{Al}(\mathrm{OTf})_{3}$ & $\mathrm{MeOH}$ & 180 & $30\left(\mathrm{H}_{2}\right)$ & 2 & $34 \%$ methoxypropylsyringol, $8 \%$ methoxypropylguaiacol & 55 & [57] \\
\hline 38 & 2017 & oak & $\mathrm{Pd} / \mathrm{C}+\mathrm{Al}(\mathrm{OTf})_{3}$ & $\mathrm{MeOH}$ & 180 & $30\left(\mathrm{H}_{2}\right)$ & 2 & $12 \%$ methoxypropylsyringol, $10 \%$ propanolsyringol & 46 & [58] \\
\hline 39 & 2017 & birch & $\mathrm{NiFe} / \mathrm{C}$ & $\mathrm{MeOH}$ & 200 & $20\left(\mathrm{H}_{2}\right)$ & 6 & 24\% 4-propylsyringol, $11 \%$ 4-propylguaiacol & 40 & [59] \\
\hline 40 & 2017 & pinus radiata & $\mathrm{Pd} / \mathrm{C}$ & Dioxane $/ \mathrm{H}_{2} \mathrm{O}(1: 1)$ & 195 & $34\left(\mathrm{H}_{2}\right)$ & 24 & $22 \%$ propanolguaiacol, $3 \%$ propylguaiacol & $78^{+}$ & [60] \\
\hline 41 & 2017 & birch & $\mathrm{Ni} / \mathrm{Al}_{2} \mathrm{O}_{3}$ & $\mathrm{MeOH}$ & 250 & $30\left(\mathrm{H}_{2}\right)$ & 3 & $21 \%$ propanolsyringol, $5 \%$ propylsyringol & 36 & [4] \\
\hline 42 & 2017 & birch & $\mathrm{H}_{3} \mathrm{PO}_{4}+\mathrm{Pd} / \mathrm{C}$ & $\mathrm{MeOH} / \mathrm{H}_{2} \mathrm{O}(7: 3)$ & 180 & $30\left(\mathrm{H}_{2}\right)$ & 3 & $18 \%$ propanolsyringol, $11 \%$ propylsyringol & 37 & [61] \\
\hline 43 & 2017 & poplar & $\mathrm{Ni} / \mathrm{C}$ & $\mathrm{MeOH}$ & 190 & $60\left(\mathrm{H}_{2}\right)$ & 3 & $12 \%$ propylguaiacol and propylsyringol & 17 & [62] \\
\hline
\end{tabular}


Table 1. Cont.

\begin{tabular}{|c|c|c|c|c|c|c|c|c|c|c|}
\hline \multirow[t]{2}{*}{ Entry } & \multirow[t]{2}{*}{ Year } & \multirow[t]{2}{*}{ Feedstock } & \multirow[t]{2}{*}{ Catalyst } & \multirow[t]{2}{*}{ Solvent } & \multicolumn{3}{|c|}{ Reaction Conditions } & \multirow{2}{*}{$\begin{array}{l}\text { Yield of Main Products } \\
\text { wt \% }\end{array}$} & \multirow{2}{*}{$\begin{array}{l}\text { Lignin Monomer } \\
\text { Yield (wt \%) }\end{array}$} & \multirow[t]{2}{*}{ Reference } \\
\hline & & & & & $\mathrm{T}\left({ }^{\circ} \mathrm{C}\right)$ & $\mathrm{p}(\mathrm{bar})$ & $\mathrm{t}(\mathrm{h})$ & & & \\
\hline 44 & 2018 & poplar & $\mathrm{Ni} / \mathrm{C}$ & $\mathrm{MeOH}$ & 200 & $30\left(\mathrm{H}_{2}\right)$ & 1 & $8 \%$ propylsyringol, $5 \%$ propylguaiacol & 48 & [63] \\
\hline 45 & 2018 & pine & $\mathrm{Cu}_{20} \mathrm{PMO}$ & $\mathrm{MeOH}$ & 220 & $40\left(\mathrm{H}_{2}\right)$ & 18 & $8 \%$ propanolguaiacol, $4 \%$ propylguaiacol & 13 & [64] \\
\hline 46 & 2018 & birch & $\mathrm{Ru} / \mathrm{C}+\mathrm{H}_{4} \mathrm{SiW}_{12} \mathrm{O}_{40}$ & petrol $/ \mathrm{H}_{2} \mathrm{O}$ & 220 & $50\left(\mathrm{H}_{2}\right)$ & 5 & $21 \%$ propanolsyringol, $5 \%$ propylsyringol & 39 & [65] \\
\hline 47 & 2018 & poplar, spruce & Raney-Ni, $\mathrm{Ni}_{2} \mathrm{P} / \mathrm{SiO}_{2}$ & $2-\mathrm{PrOH} / \mathrm{H}_{2} \mathrm{O}(7: 3)$ & 180 & autogenous & 3 & $50-60 \%$ phenolic species & $20-25$ & [66] \\
\hline 48 & 2018 & poplar, spruce & Raney-Ni & $2-\mathrm{PrOH} / \mathrm{H}_{2} \mathrm{O}(7: 3)$ & 200 & autogenous & 6 & & & [67] \\
\hline 49 & 2018 & sorghum & Fenton & EtOH & 250 & autogenous & 12 & phenolic oil & 76 & [68] \\
\hline 50 & 2018 & oak & $\mathrm{Al}(\mathrm{OTf})_{3}+\mathrm{Pd} / \mathrm{C}$ & $\mathrm{MeOH}$ & 160 & autogenous & 2 & $9 \%$ propylsyringol, $5 \%$ propylguaiacol & 25 & [69] \\
\hline 51 & 2018 & cornstalk & $\mathrm{Ru} / \mathrm{C}$ & $\mathrm{H}_{2} \mathrm{O}$ & 200 & $30\left(\mathrm{H}_{2}\right)$ & 8 & $67 \%$ ethylcyclohexane, $16 \%$ propylcyclohexane & $97^{*}$ & [70] \\
\hline 52 & 2018 & birch & $\mathrm{Pd} / \mathrm{C}+\mathrm{Yb}(\mathrm{OTf})_{3}$ & $\mathrm{MeOH}$ & 250 & $20\left(\mathrm{H}_{2}\right)$ & 20 & lignin-oil & $83 *$ & [71] \\
\hline 53 & 2018 & eucalyptus & $\mathrm{Ru} / \mathrm{C}$ & $\mathrm{BuOH} / \mathrm{H}_{2} \mathrm{O}(1: 1)$ & 200 & $30\left(\mathrm{H}_{2}\right)$ & 2 & $41 \%$ propanolsyringol and propanolguaiacol & 49 & [72] \\
\hline 54 & 2018 & bark & $\mathrm{Pd} / \mathrm{C}$ & $\mathrm{MeOH} / \mathrm{H}_{2} \mathrm{O}(2: 1)$ & 200 & & 2 & $3 \%$ ethylguaiacol & 42 & [73] \\
\hline 55 & 2018 & vanilla seeds & $\mathrm{Ni} / \mathrm{C}$ & $\mathrm{MeOH}$ & 250 & $30\left(\mathrm{H}_{2}\right)$ & 3 & $18 \%$ propylcatechol, $3 \%$ propenylcatechol & 21 & [74] \\
\hline 56 & 2018 & corncob & $\mathrm{ZnMoO}_{4} / \mathrm{MCM}-41$ & $\mathrm{MeOH}$ & 220 & $30\left(\mathrm{H}_{2}\right)$ & 4 & $16 \%$ methyl coumarate, $13 \%$ methyl ferulate & 38 & [75] \\
\hline 57 & 2018 & cork & $\mathrm{Rh} / \mathrm{C}$ & $\begin{array}{l}\text { 2-methyl } \\
\text { tetrahydrofuran }\end{array}$ & 200 & $40\left(\mathrm{H}_{2}\right)$ & 4 & bio-oil & 43 & [76] \\
\hline 58 & 2018 & apple wood & $\mathrm{Ru} / \mathrm{SiC}$ & $\mathrm{MeOH}$ & 250 & $10\left(\mathrm{H}_{2}\right)$ & 3 & propylsyringol and ethylsyringol & 48 & [77] \\
\hline 59 & 2018 & corn stover & $\mathrm{MoS}_{2}$ & $\mathrm{MeOH}$ & 20 & $30\left(\mathrm{H}_{2}\right)$ & 2 & $4 \%$ propylguaiacol, $3 \%$ ethylphenol & 18 & [78] \\
\hline 60 & 2018 & birch & $\mathrm{CdS}$ & $\mathrm{MeOH} / \mathrm{H}_{2} \mathrm{O}$ & r.t. & $1\left(\mathrm{~N}_{2}\right)$ & 8 & $14 \%$ propanonesyringol, $7 \%$ propanoneguaiacol & 27 & [79] \\
\hline 61 & 2019 & birch & Co-phen/C & $\mathrm{EtOH} / \mathrm{H}_{2} \mathrm{O}(1: 1)$ & 200 & autogenous & 4 & $10 \%$ 4-propylsyringol, $9 \%$ 4-propenylsyringol & 34 & [80] \\
\hline 62 & 2019 & oak & $\mathrm{Ni}-\mathrm{Al} / \mathrm{AC}$ & $\mathrm{HCOOH} / \mathrm{EtOH} / \mathrm{H}_{2} \mathrm{O}$ & 190 & autogenous & 3 & $9 \%$ propylsyringol, $5 \%$ propylguaiacol & $23^{x}$ & [81] \\
\hline 63 & 2019 & birch & $\mathrm{Pt} / \mathrm{Al}_{2} \mathrm{O}_{3}$ & $\mathrm{MeOH} / \mathrm{H}_{2} \mathrm{O}(1: 2)$ & 230 & autogenous & 3 & $40 \%$ propylsyringol, $6 \%$ propylguaiacol & 49 & [82] \\
\hline 64 & 2019 & poplar & Raney-Ni & $2-\mathrm{PrOH} / \mathrm{H}_{2} \mathrm{O}(7: 3)$ & 200 & autogenous & 3 & $11 \%$ propanolsyringol, $10 \%$ propanolguaiacol & 34 & [83] \\
\hline 65 & 2019 & poplar, spruce & Raney-Ni & $2-\mathrm{PrOH} / \mathrm{H}_{2} \mathrm{O}(7: 3)$ & 220 & autogenous & 3 & $10 \%$ ethylsyringol, $7 \%$ propylsyringol & 36 & [84] \\
\hline 66 & 2019 & poplar & $\mathrm{Ni} / \mathrm{C}$ & $\mathrm{MeOH}$ & 225 & $35\left(\mathrm{H}_{2}\right)$ & 12 & propylsyringol, propylguaiacol & 90 & [85] \\
\hline 67 & 2019 & apple wood & $\mathrm{Mo}_{\mathrm{x}} \mathrm{C} / \mathrm{CNT}$ & $\mathrm{MeOH}$ & 250 & $10\left(\mathrm{H}_{2}\right)$ & 3 & propylsyringol, propylguaiacol & 42 & [86] \\
\hline 68 & 2019 & eucalyptus & Ni@ZIF-8 & $\mathrm{MeOH}$ & 260 & $30\left(\mathrm{H}_{2}\right)$ & 8 & $24 \%$ propylsyringol + propylguaiacol & 44 & [87] \\
\hline 69 & 2019 & basswood & binuclear Rh complex & $\mathrm{NaOH} / \mathrm{H}_{2} \mathrm{O}$ & 110 & $1(\mathrm{Ar})$ & 24 & $2 \%$ propanonesyringol, $1.6 \%$ ethanonesyringol & 5 & [88] \\
\hline 70 & 2020 & poplar & binuclear Rh complex & $\mathrm{NaOH} / \mathrm{H}_{2} \mathrm{O}$ & 110 & $1(\mathrm{Ar})$ & 12 & $9 \%$ ethanonesyringol, $6 \%$ ethanoneguaiacol & 17 & [89] \\
\hline 71 & 2020 & birch & $\mathrm{Ru} / \mathrm{C}$ & $\mathrm{MeOH}$ & 235 & $30\left(\mathrm{H}_{2}\right)$ & 3 & $20 \%$ phenol, $9 \%$ propylene & 29 & [90] \\
\hline 72 & 2020 & $\begin{array}{c}\text { eucalyptus } \\
\text { sawdust }\end{array}$ & $\mathrm{Ru} / \mathrm{C}$ & $\mathrm{BuOH} / \mathrm{H}_{2} \mathrm{O}(1: 1)$ & 200 & $30\left(\mathrm{H}_{2}\right)$ & 2 & propanol-substituted phenolics & 49 & [91] \\
\hline 73 & 2020 & pine & $\mathrm{H}_{2} \mathrm{SO}_{4}$ & dimethyl carbonate & 140 & autogenous & 0.67 & $8 \%$ G-C2-acetal & 9 & [92] \\
\hline 74 & 2020 & eucalyptus & $\mathrm{Pd} / \mathrm{C}$ & $\mathrm{MeOH}$ & 240 & $30\left(\mathrm{H}_{2}\right)$ & 4 & $32 \%$ propanolsyringol, $13 \%$ propanolguaiacol & 50 & [93] \\
\hline 75 & 2020 & beech & $\mathrm{NiMo} / \mathrm{Al}_{2} \mathrm{O}_{3}$ & $\mathrm{EtOH}$ & 260 & $26\left(\mathrm{H}_{2}\right)$ & 3 & $11 \%$ propylsyringol, $6 \%$ propylguaiacol & 20 & [94] \\
\hline 76 & 2020 & pine & $\mathrm{Pt} / \mathrm{C}$ & $\mathrm{MeOH} / \mathrm{H}_{2} \mathrm{O}$ & 230 & $30\left(\mathrm{H}_{2}\right)$ & & $10 \mathrm{~mol} \%$ phenol & 15 & [95] \\
\hline 77 & 2020 & birch & H-BEA & $\mathrm{EtOH} / \mathrm{H}_{2} \mathrm{O}$ & 220 & & 2 & & 20 & [96] \\
\hline 78 & 2020 & poplar & & & 250 & autogenous & 0.33 & & & [97] \\
\hline 79 & 2020 & birch & & $\mathrm{H}_{2} \mathrm{O}$ & 195 & & & & & [98] \\
\hline 80 & 2020 & poplar & emimAce & emimAce & 110 & 1(air) & 4 & $38 \%$ lignin & & [99] \\
\hline 81 & 2020 & maple & Zr-KIT-5 & $\gamma$-valerolactone & 250 & $30\left(\mathrm{H}_{2}\right)$ & 18 & $\begin{array}{c}\text { 3.5\% 2-phenylpropan-2yl acetate, 1.6\% } \\
\text { 3,4-dimethoxyphenol }\end{array}$ & 7 & [100] \\
\hline
\end{tabular}




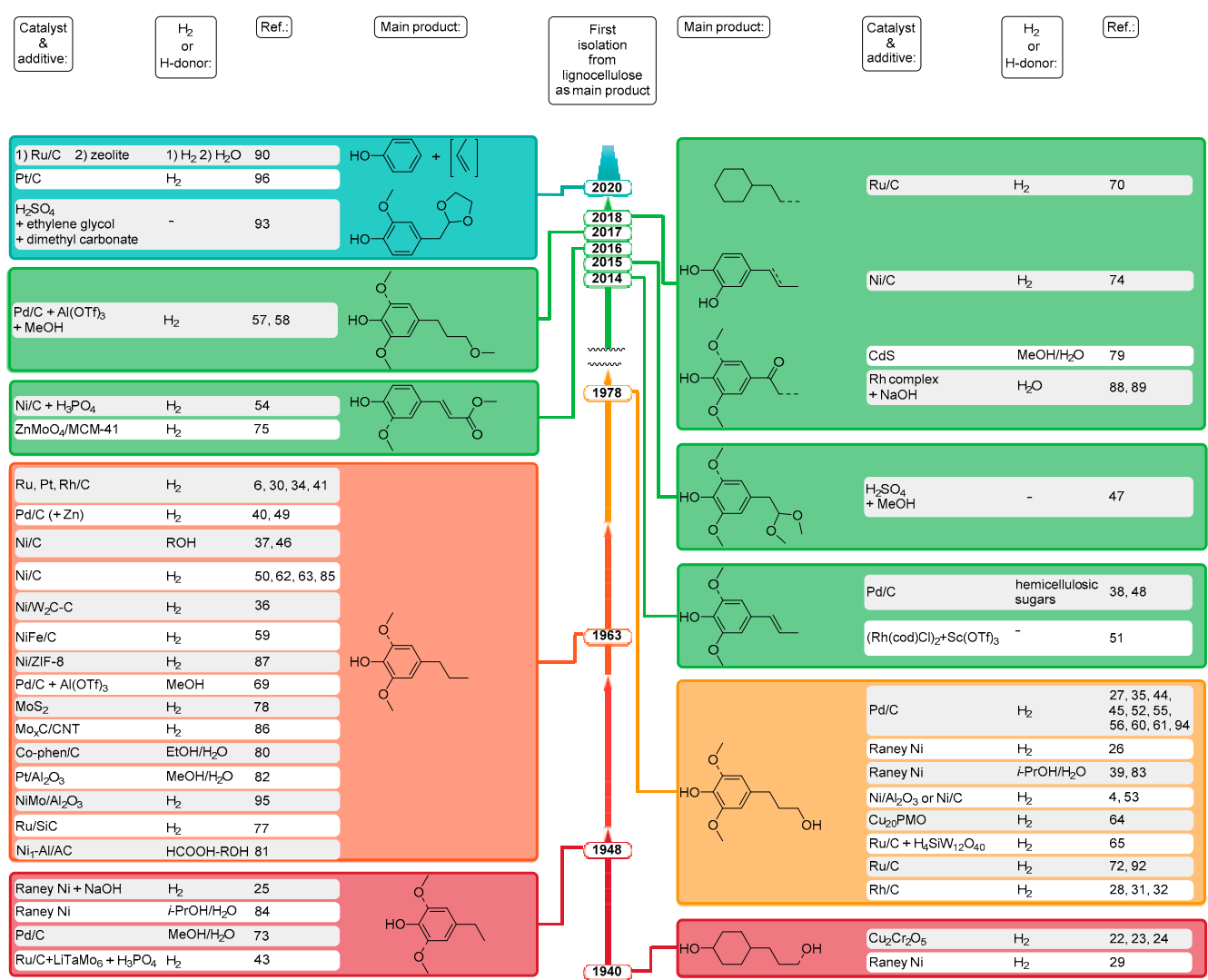

Figure 4. Main lignin monomeric products with functionalized sidechains, the date of their first isolation from lignocellulose as main product, typical catalysts, and additives with added hydrogen or hydrogen donors applied in the process, and literature references. For simplicity, guaiacols are not shown if the same syringol derivatives exist as main product. The detailed process characteristics and monomer yields of each individual study can be found in Table 1.

\section{Chronological Overview}

\subsection{From 1940 to 2014}

Originally, high pressure hydrogenation and hydrogenolysis of wood dates back to the 1940s with the aim of clarifying lignin structure [19]. Various woods (maple, aspen, spruce) were hydrogenated using copper-chromite, Raney-Ni, $\mathrm{Pd} / \mathrm{C}$, or $\mathrm{Rh} / \mathrm{C}$ catalysts in dioxane(/water) solvent (mixture) under various conditions $\left(173-280^{\circ} \mathrm{C}, 35-333\right.$ bar $_{2}, 5-20 \mathrm{~h}$ reaction time) resulted in $17-59 \mathrm{wt} \%$ monomer yields with 4-propylcyclohexanol (1940) [22], 4-ethylsyringol (1948) [25], 4-propylsyringol (1963) [26], 4-propanolguaiacol (1966) [27], and 4-propanolsyringol (1978) [30] as main products (entries 1-11 in Table 1 and Figure 4) [22-32]. Under harsh reaction conditions $\left(250-280^{\circ} \mathrm{C}, 240-333 \mathrm{bar} \mathrm{H}_{2}\right.$ pressure) not only saturation of the benzene ring occurred, but also hydrogenation and hydrogenolysis of the holocellulose part took place [5,22-24]. The 4-n-propylphenol nature of the lignin monomers was confirmed in these early studies [5]. The efficiency of various $(\mathrm{Ni}, \mathrm{Pd}, \mathrm{Rh}$, and $\mathrm{Ru}$ ) catalysts was compared for the hydrogenolysis of spruce wood under mild reaction conditions $\left(195{ }^{\circ} \mathrm{C}, 35 \mathrm{bar}\right.$ $\mathrm{H}_{2}$ ), the $\mathrm{Pd} / \mathrm{C}$ catalyzed reaction gave the highest (16\%) 4-propanolguaiacol yield, and the highest monomeric yield (34\%) was obtained when $\mathrm{Rh} / \mathrm{C}$ was used $[5,28]$. An increased monomers yield was demonstrated when softwood was replaced by hardwood [30], and hydrogen pressure did not affect the yield [31]. The increased monomers yield of hardwood can be explained by its higher $\mathrm{S}$ to $\mathrm{G}$ ratio compared to softwood, and therefore less $\mathrm{C}-\mathrm{C}$ bonds, as was explained in the introduction.

Later, (1993-2011) new feedstocks (rice husks [33], birch [34], pine [35]) and catalysts (polyvalent metals [33], $\mathrm{H}_{3} \mathrm{PO}_{4}+\mathrm{Pt} / \mathrm{C}$ [34]) were tried in the dioxane(/water) solvent (mixture) under similar 
conditions and similar main products (4-propylsyringol and 4-propanolguaiacol) with comparable monomer yields (22-46 wt \%) were gained (entries 12-14 in Table 1 and Figure 4). Four catalysts $(\mathrm{Ru} / \mathrm{C}, \mathrm{Pd} / \mathrm{C}, \mathrm{Rh} / \mathrm{C}$, and $\mathrm{Pt} / \mathrm{C})$ were tested for birch treatment and the monomer yields depended on the applied conditions: the total yield of monomers was $34 \%$ over the $\mathrm{Pt} / \mathrm{C}$ catalyst, it was improved to $38 \%$ with addition of acid $\left(\mathrm{H}_{3} \mathrm{PO}_{4}\right)$, the addition of dioxane further improved the yield to $46 \%$ [34]. The effect of additives was demonstrated in this work. Beside dimeric and oligomeric products, 4-propanolguaiacol was produced as a monomeric product almost exclusively in the $\mathrm{Pd} / \mathrm{C}$ catalyzed hydrogenolysis of Pinus radiata wood [35]. Birch was converted in new solvents (ethylene glycol [36], methanol [37], ethanol/water mixture [38]) over new catalysts ( $\mathrm{Ni}-\mathrm{W}_{2} \mathrm{C} / \mathrm{C}$ [36], Ni/C [37]) with high $(47-54 \mathrm{wt} \%)$ monomer yields. Two processes [37,38] did not require addition of external hydrogen, alcohol solvents provided the active hydrogen species. One major monomeric product was generated in some processes (entries 12, 14, and 17 in Table 1) and a new one (4-propenylsyringol) appeared in 2014 (Figure 4) [33,35,38].

In 2012, Zhang and co-workers [36] described the direct conversion of birch over a Ni- $\mathrm{W}_{2} \mathrm{C} / \mathrm{C}$ catalyst in a one-pot one-step reductive catalytic depolymerization process: the carbohydrate fraction was converted to ethylene glycol and other diols with a total yield of $76 \%$, while the lignin component was transformed selectively into monophenols with a yield of $47 \%$ (entry 15 in Table 1 and 18\% 4-propylsyringol in Figure 4). Different feedstocks, solvents and catalysts were tested. Hardwood, compared to softwood, led to a better conversion of both lignin and carbohydrates as expected. Replacing the original water solvent to methanol and later to ethylene glycol resulted increasing monophenol yields. Using a $\mathrm{Pd} / \mathrm{C}$ catalyst led to the highest selectivity (56\%) towards 4-propanolsyringol. This method uses high pressure (60 bar) hydrogen gas due to the complete conversion of all lignocellulose components (route $c$ in Figure 2) [36].

In 2014, Ferrini and Rinaldi [39] realized that lignin was released solvolytically from the plant cell by simply "cooking" wood in the presence of Raney-Ni in 2-propanol (2-PrOH)/ $\left.\mathrm{H}_{2} \mathrm{O}\right)$ and partially depolymerized lignin, a non-pyrolytic lignin bio-oil was produced in addition to pulps that are amenable to enzymatic hydrolysis. The suspension of wood pellets, Raney Ni catalyst and aqueous solution of 2-propanol was heated under mechanical stirring (e.g., at $180^{\circ} \mathrm{C}$ for $3 \mathrm{~h}$ ) and $25 \mathrm{wt} \%$ lignin oil and $71 \mathrm{wt} \%$ pulp were produced (entry 18 in Table 1). The lignocellulosic feed was processed in the absence of molecular hydrogen and acetone generated by the hydrogen transfer can be hydrogenated to 2-PrOH. The holocellulose fraction or pulp (i.e., cellulose and hemicellulose) was isolated by filtration and washed with the 2-PrOH/water solution. Raney $\mathrm{Ni}$ was removed from the suspension with a magnet. Finally, the non-pyrolytic lignin bio-oil was isolated by solvent removal from the extracting liquor. This lignin oil is readily susceptible to further hydroprocessing (hydrodeoxygenation) under low-severity conditions. The complexity of the low-molecular weight lignin product mixture is a disadvantage, but the autogenous hydrogen usage and lignin-only conversion are advantages of this method. The pulp (holocellulose) is suitable for the production of glucose and xylose through enzymatic hydrolysis [39].

\subsection{5}

Lignin-first biorefineries were described in two works in 2015. Abu-Omar et al. [40] presented a selective hydrogenolysis of poplar wood with bimetallic $\mathrm{Zn}-\mathrm{Pd} / \mathrm{C}$ in methanol with external $\mathrm{H}_{2}$, focusing on the lignin monomers (30\% 4-propylsyringol and 24\% 4-propylguaiacol) and the enzymatic conversion of the retained pulp to glucose in 95\% yield (entry 19 in Table 1). Sels et al. [41] presented reductive lignocellulose fractionation of birch sawdust through simultaneous solvolysis and catalytic hydrogenolysis in the presence of $\mathrm{Ru} / \mathrm{C}$ in methanol under hydrogen at $250{ }^{\circ} \mathrm{C}$ resulting in carbohydrate pulp and lignin oil. The thermal and solvolytic disassembly of lignin (delignification) was immediately followed by the reductive stabilization of lignin's most reactive intermediates into soluble and stable low-molecular-weight phenolic products. This fractionation strategy was denominated as a 'lignin-first' biorefinery, as the valorization of lignin to chemicals was performed before carbohydrate processing. 
The lignin oil yields above $50 \%$ of phenolic monomers (mainly 4-propylguaiacol and 4-propylsyringol) and about $20 \%$ of a set of phenolic dimers, relative to the original lignin content, next to phenolic oligomers. The separated carbohydrate pulp contains up to $92 \%$ of the initial polysaccharides (entry 20 in Table 1).

In a patent in 2015, Sels et al. described an interesting biorefinery concept for the direct production of light naphtha (hexane, pentane, methyl cyclopentane, cyclohexane, etc.) for converting lignocellulose in the presence of an acidic reactive aqueous phase and a redox catalyst $\left(\mathrm{Ru} / \mathrm{C}+\mathrm{H}_{4} \mathrm{SiW}_{12} \mathrm{O}_{40}\right)$ in the organic extracting/reaction phase (entry 21 in Table 1) [42]. The products are useful as feedstock for steam and catalytic cracking, as precursors for the synthesis of bioaromatics, and as fuel additives. Another one-pot lignocellulose conversion into gasoline alkanes and monophenols was published by $\mathrm{Ma}$ et al. [43]. Raw biomass feedstocks (pine, corn, wheat, rice, etc.) were processed with $\mathrm{Ru} / \mathrm{C}+\mathrm{LiTaMoO}_{6}$ catalysts in phosphoric acid and pentanes and hexanes were produced from the carbohydrates with up to $82 \%$ total yield and monophenols, related alcohols and hydrocarbons from the lignin fraction. Partial hydrocracking of the monophenol fraction was suggested (entry 22 in Table 1).

Propylphenolics and propanolphenolics are the most abundant main lignin monomeric products using $\mathrm{Ru} / \mathrm{C}+\mathrm{H}_{2}$ and $\mathrm{Pd} / \mathrm{C}+\mathrm{H}_{2}$ catalytic systems, respectively, as shown in Figure 4. Accordingly, changing the catalyst from $\mathrm{Ru} / \mathrm{C}$ to $\mathrm{Pd} / \mathrm{C}$ drastically increased the $\mathrm{OH}$-content of the phenolic monomers (entry 23 in Table 1) [44], and the solvent choice (methanol and ethylene glycol) has an impact on both pulp retention and delignification efficiency [45]. Reductive catalytic fractionation (RCF), as a new expression, was used first (2015) in the latter paper [45]. The effect of substrate and catalyst loading was studied over $\mathrm{Ni} / \mathrm{C}$ catalyst in methanol: birch resulted higher monomer yields than poplar and eucalyptus, while higher catalysts loading caused higher monomer yields due to the presence of more hydrogen produced from methanol reforming [46].

As an example of metal-free catalytic systems (entry 26 in Table 1), the acid-catalyzed degradation of cedar and eucalyptus wood samples in a toluene-methanol solvent mixture resulted in selective production of lignin monomers, homovanillyl aldehyde dimethyl acetal and homosyringaldehyde dimethyl acetal (by 2015 in Figure 4), due to the trapping of enol intermediates with alcohol [47].

\subsection{6}

Luterbacher et al. reported that adding formaldehyde during biomass pretreatment followed by reductive depolymerization of this stabilized lignin over $\mathrm{Ru} / \mathrm{C}$ as catalyst in methanol, produced guaiacyl and syringyl monomers at near theoretical yields ( $78 \mathrm{~mol} \%$ for poplar) during hydrogenolysis (entry 27 in Table 1). These yields were three to seven times higher than those obtained without formaldehyde, which prevented lignin condensation by forming 1,3-dioxane structures with lignin side-chain hydroxyl groups [6].

In 2016, the utilization of hemicellulose as a hydrogen donor for the reductive lignin transformations and the separation of biomass into three main components: solid carbohydrate residue (mainly cellulose), liquid bio-oil (mainly lignin monomers and oligomers), and water-solubilized sugars (originating mainly from hemicellulose) emerged as a new idea [48]. Usage of $\mathrm{Zn}^{\mathrm{II}}$ as a co-catalyst beside $\mathrm{Pd} / \mathrm{C}$ increased the selectivity toward 4-propylsyringol and 4-propylguaiacol production (entry 29 in Table 1) through removal of the hydroxyl group at the $C_{\gamma}$ position of the $\beta$-O-4 ether linkage [49]. All three major components of Miscanthus biomass (lignin, cellulose, and hemicellulose) were effectively (with $55 \%$ overall conversion) utilized into high value chemicals with mass balance of $98 \%$ using a $\mathrm{Ni} / \mathrm{C}$ catalyst over $68 \%$ yield into four phenolic products from lignin (entry 30 in Table 1) [50].

Bruijnincx et al. described a tandem catalysis process for ether linkage cleavage within lignin, involving ether hydrolysis by water-tolerant Lewis acids (metal triflates) followed by aldehyde decarbonylation by a Rh complex (entry 31 in Table 1) [51]. In situ decarbonylation of the reactive aldehydes limited loss of monomers by recondensation, and surprisingly 4-(1-propenyl)phenols (4-propenylsyringol for poplar) were the main monomeric products (Figure 4). Hensen et al., also used 
metal triflate $\left(\mathrm{Yb}(\mathrm{OTf})_{3}\right)$ catalysts for rapid cleavage of the chemical bonds between lignin and carbohydrates combined with $\mathrm{Pd} / \mathrm{C}$ hydrogenolysis catalysts and $36-48 \%$ aromatic monomer yields (4-propanol derivatives, entry 32 in Table 1) were reached from different woods in the tandem process [52]. Xu et al. efficiently hydrogenated beech to natural phenolic alcohols (4-propanolsyringol and 4-propanolguaiacol) with $51 \%$ total yield using $\mathrm{Ni} / \mathrm{C}$ catalyst in a methanol-water co-solvent (entry 33 in Table 1) [53]. Breaking the intramolecular hydrogen bonds in lignin $\beta-\mathrm{O}-4$ motifs accelerated the $\mathrm{C}_{\beta}-\mathrm{O}$ cleavage, maintaining the original structure of lignin [53].

Román-Leshkov et al. investigated the RCF of corn stover using $\mathrm{Ru} / \mathrm{C}$ and $\mathrm{Ni} / \mathrm{C}$ catalysts and $\mathrm{H}_{3} \mathrm{PO}_{4}$ cocatalyst in methanol at 200 and $250{ }^{\circ} \mathrm{C}$ [54]. The monomer yields increased up to $38 \%$ as a function of time, with the addition of acid cocatalyst, and methyl coumarate/ferulate (2016 in Figure 4) were the main products (entry 34 in Table 1). Clear trade-offs existed between the levels of lignin extraction, monomer yields, and carbohydrate retention in the residual solids [54].

The influence of acidic and alkaline additives was studied on the $\mathrm{Pd} / \mathrm{C}$-catalyzed reductive processing of poplar wood in methanol: under acidic $\left(\mathrm{H}_{3} \mathrm{PO}_{4}\right)$ conditions both delignification (to 4-propanolsyringol/guaiacol as main monomeric products, entry 35 in Table 1) and alcoholysis of hemicellulose are promoted, leaving behind a cellulose-rich pulp, alkaline $(\mathrm{NaOH})$ conditions also enhanced delignification, but other lignin products $\left(C_{2}\right.$-substituted phenolics with loss of hydroxyl groups) were formed, lignin depolymerization was hampered, and cellulose loss was found in the pulp [55]. Synergetic effects of alcohol/water mixing were studied under similar conditions but without acid/alkaline addition in another paper. Low $(30 \mathrm{vol} \%)$ water concentrations enhanced the removal of lignin from the biomass, while the majority of the carbohydrates were left untouched, high (70 vol \%) water concentrations favored the solubilization of both hemicellulose and lignin, resulting in a cellulosic residue of higher purity [56].

\subsection{7}

The tandem metal triflate and $\mathrm{Pd} / \mathrm{C}$ catalysis was further investigated by the Hensen group in 2017. Metal triflates were involved in cleaving not only ester and ether linkages between lignin and the carbohydrates, but also $\beta$-O-4 ether linkages within the aromatic lignin structure $\mathrm{Pd} / \mathrm{C}$ is required for cleaving $\alpha-\mathrm{O}-4,4-\mathrm{O}-5$ and $\beta-\beta$ linkages. Synergy was revealed between $\mathrm{Pd} / \mathrm{C}$ and metal triflates: under optimized conditions, $55 \mathrm{wt} \%$ mono-aromatics (entry 37 in Table 1)—mainly alkylmethoxyphenols (2017 in Figure 4)—were obtained from the lignin fraction (24 wt \%) of birch wood [57]. Instead of metal triflates the effect of possible alternative acid co-catalysts $\left(\mathrm{HCl}, \mathrm{H}_{2} \mathrm{SO}_{4}, \mathrm{H}_{3} \mathrm{PO}_{4}\right.$, and $\left.\mathrm{CH}_{3} \mathrm{COOH}\right)$ was studied for the tandem RCF process in another publication [58]. $\mathrm{Al}(\mathrm{OTf})_{3}$ and $\mathrm{HCl}$, respectively, afforded $46 \mathrm{wt} \%$ (entry 38 in Table 1 ) and $44 \mathrm{wt} \%$ lignin monomers from oak wood sawdust in tandem catalytic systems with $\mathrm{Pd} / \mathrm{C}$ at $180{ }^{\circ} \mathrm{C}$ in $2 \mathrm{~h}$, therefore $\mathrm{HCl}$ is a promising alternative to the metal triflates [58].

Birch was effectively depolymerized using $\mathrm{Ni}-\mathrm{Fe} / \mathrm{C}$ catalyst with alloy structure in methanol reaching $40 \%$ monomer yield (entry 39 in Table 1) with $88 \%$ selectivity to 4-propylsyringol and 4-propylguaiacol [59]. Pinus radiata wood was depolymerized by mild hydrogenolysis in dioxane-water mixture by $\mathrm{Pd} / \mathrm{C}$ catalyst to give an oil product, from which new biobased epoxy resins were prepared [60].

The role of $\mathrm{Ni} / \mathrm{Al}_{2} \mathrm{O}_{3}$ catalyst was elucidated in the solubilization, depolymerization, and stabilization of lignin from birch in methanol in the 2017 work of Sels et al. [4]: the solvent is responsible for the first two processes, while the catalyst is for the stabilization through hydrogenation of reactive intermediates. Recuperation and reuse of the $\mathrm{Ni} / \mathrm{Al}_{2} \mathrm{O}_{3}$ pellets was facilitated using a catalyst basket. This catalytic reduction also prevents undesirable repolymerization reactions.

Continuous systems are vital for realistic scale-up because time-resolved product distributions and yields can be obtained from these experiments. The first two papers using flow-through systems instead of batch reactors for RCF were published by Samec [61] and Román-Leshkov [62] in 2017. During RCF in a flow-through system, separate reactors are used for pulping and delignification 
processes (Figure 5). A percolation reactor filled with birch and consecutively a fixed catalytic bed reactor filled with $\mathrm{Pd} / \mathrm{C}$ catalyst was used in the first paper [61]. A methanol-water solution of phosphoric acid was percolated through the system at 30 bar pressure (left reactor system in Figure 5); under optimized conditions $37 \%$ yield of monophenolic compounds (18\% propanolsyringol and $11 \%$ propylsyringol) was reached (entry 42 in Table 1). It was concluded that organosolv pulping and transfer hydrogenolysis should be performed under different conditions; and depolymerized lignin can be obtained without the palladium catalyzed step [61]. Two flow-through systems were used in the second paper [62]: a single-bed reactor with a biomass bed located upstream from a catalyst bed and a dual-bed reactor featuring switchable biomass beds physically separated from the catalyst in a separate upstream reactor (right reactor system in Figure 5). RCF of poplar with Ni/C catalyst in methanol solvent was studied in the latter paper, 17\% monomer yield (mainly propylguaiacol and propylsyringol) was reached (entry 43 in Table 1). It was concluded that flow-through studies allowed the observation of biomass extraction intermediates, decoupling of solvolysis and hydrogenolysis, simple catalyst recovery and recyclability, and elucidated catalyst deactivation mechanisms [62].

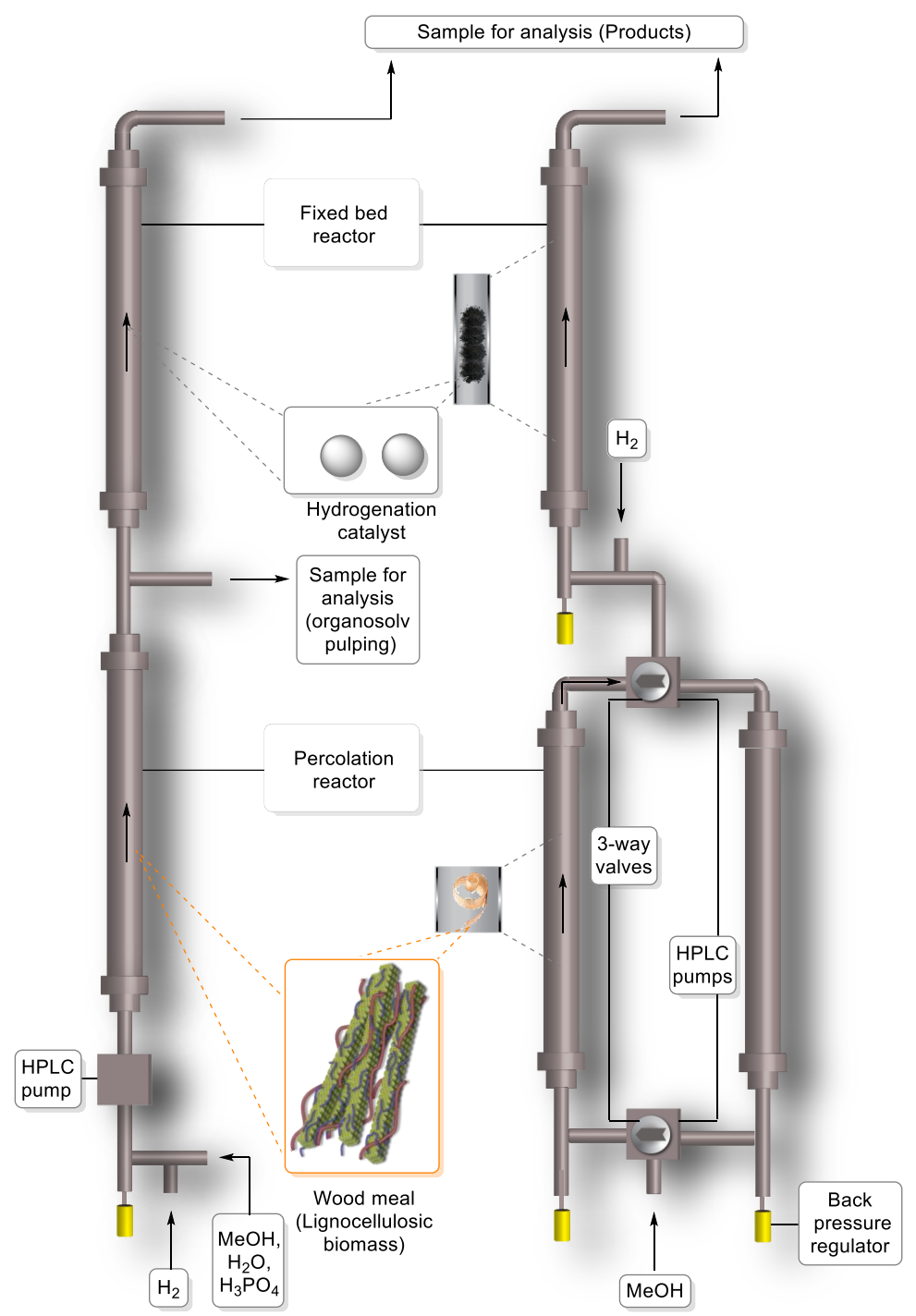

Figure 5. Schematic representations of semi-continuous flow-through reactor systems. (Left) Combination of a percolation reactor filled with woody biomass and a fixed catalytic bed reactor filled with $\mathrm{Pd} / \mathrm{C}$ catalyst (Adapted from [61]). (Right) Schematic of the semi-continuous dual-bed flow reactor. Biomass in lower beds, catalyst in upper bed. (Adapted from [62,63]). 


\subsection{8}

Continuous systems initiated by Román-Leshkov et al. [62] were developed further in 2018 [63]. Kinetic studies of RCF in flow-through reactors revealed decoupling of the two limiting mechanistic steps, lignin solvolysis and reduction, which can be independently controlled. The difference of activation barriers between flow and batch reactors indicated that lignin extraction under typical RCF conditions was mass-transfer limited [63].

Complete lignocellulose conversion yielding valuable aromatics and fuels was introduced by Barta et al. [64]. In the first, mild depolymerization step following the principles of RCF using $\mathrm{Cu}_{20} \mathrm{PMO}$ (porous metal oxide), propanolguaiacol was obtained as main monomeric product (entry 45 in Table 1) that could be converted to plethora of value-added aromatic building blocks, also including amines. In the second step, the cellulose and unreacted lignin residues that were mixed with the heterogeneous catalyst were converted in supercritical methanol, resulting in aliphatic alcohols. Hydrothermal conditions suitable for full conversion of the residues allows for efficient catalyst recycling. Value-added products were produced in further catalytic pathways.

A comprehensive strategy for the smooth integration of an RCF-based biorefinery process into current petrorefinery schemes was carried out by Sels and coworkers [65]. Birch wood processed by RCF provided nearly theoretical amounts of phenolic monomers (entry 46 in Table 1 and Figure 4) and a solid carbohydrate pulp with $83 \% \mathrm{C}_{5}$ and $93 \% \mathrm{C}_{6}$ sugar retention in the presence of $\mathrm{Ni} / \mathrm{Al}_{2} \mathrm{O}_{3}$ using methanol solvent [4]. This pulp can be converted either into bioethanol by fermentation [4] or to alkanes using liquid phase cellulose-to-naphtha (LPCtoN) technology with petrol as the organic solvent [65]. Bio-enriched gasoline was produced from the (hemi)cellulose pulp using a two-phase (water/fossil naphtha) catalytic slurry process followed by isomerization [65].

Rinaldi et al. [66] introduced a deep converting 'lignin-first' biorefinery concept in 2018, which means production of gasoline and kerosene/diesel drop-in fuels in two steps. Poplar and spruce were deconstructed over Raney $\mathrm{Ni}$ catalyst in isopropanol-water solvent mixture yielding lignin oils along with cellulosic pulps in the first step, next the lignin oils were catalytically upgraded to aliphatics or aromatics by simply changing hydrogen pressure and temperature in the presence of a $\mathrm{Ni}_{2} \mathrm{P} / \mathrm{SiO}_{2}$ catalyst (entry 47 in Table 1 ). The self-sufficiency in hydrogen was achieved through the gasification of the delignified holocellulose. The role of Raney-Ni catalyst in the process was clarified in another paper by the Rinaldi group: it suppresses formic acid formation via sugar hydrogenation [67].

Alternatively, the use of hydrogen could also be avoided through the utilization of Fenton's reagent $\left(\mathrm{Fe}^{3+}, \mathrm{H}_{2} \mathrm{O}_{2}\right)$, that combined with enzymatic hydrolysis transformed sweet sorghum bagasse into phenolic monomers and sugars [68]. Initially, the feedstock's molecular structure was modified through iron chelation and free radical oxidation via Fenton's reagent. The lignin component of the modified feedstock was then selectively depolymerized in supercritical ethanol $\left(250^{\circ} \mathrm{C}, 6.5 \mathrm{MPa}\right)$ under nitrogen to produce a phenolic oil (entry 49 in Table 1). Thus, Fenton's reagent seems to provide beneficial effect in lignin depolymerization through the modification of lignin structure by hydroxylation and demethoxylation reactions of lignin substituents in the aromatic rings as well as by the formation of an iron-lignin complex. These two modifications are considered to make the $\mathrm{B}-\mathrm{O}-4$ bond cleavage energetically more favorable. Fenton modification not only increased the yields of phenolic monomers, particularly ethyl-p-coumarate and ethyl-ferulate, but also enhanced enzymatic hydrolysis.

The metal triflate and $\mathrm{Pd} / \mathrm{C}$ catalyst system was developed further by the Hensen group in 2018 [69]. Beside $\mathrm{Al}(\mathrm{OTf})_{3}$ other homogeneous acid catalysts were tried in the first fractionation step of a two-step process, where oak was converted to lignin-oil and cellulose pulp in the first step, then to phenolic monomers with up to $25 \mathrm{wt} \%$ yield over the $\mathrm{Pd} / \mathrm{C}$ catalysts in the second step (entry 50 in Table 1). Phosphoric acid proved to be the most suitable catalyst because it minimized the repolymerization back to lignin in the first step.

A complete transformation of lignocellulose into valuable platform chemicals was reached by Wang et al. [70,71]. They transferred cornstalk into liquid alkylcyclohexanes (2018 $1^{\text {st }}$ row in Figure 4, from the lignin fraction) and polyols (from cellulose and hemicellulose components) over $\mathrm{Ru} / \mathrm{C}$ catalysts 
in aqueous phase in one step (entry 51 in Table 1) [70], and various biomasses (birch, beech, cornstalk, and pine) over $\mathrm{Pd} / \mathrm{C}+\mathrm{Yb}(\mathrm{OTf})_{3}$ catalysts in methanol solvent to bio-oil and carbohydrates in the first step (entry 52 in Table 1), then the lignin-oil to arenes over a $\mathrm{Ru} / \mathrm{Nb}_{2} \mathrm{O}_{5}$ catalyst in isopropanol, and the carbohydrates phase to 5-hydroxymethylfurfural, and furfural in tetrahydrofuran/seawater in the subsequent steps [71] in high overall yields (entries 51 and 52 in Table 1).

Another RCF process was also published by the Sels group in 2018 [72]. They converted eucalyptus into lignin-derived (mono)phenolics, hemicellulose-derived polyols, and a cellulose pulp in butanol-water 1:1 mixture over $\mathrm{Ru} / \mathrm{C}$ catalysts and 30 bar hydrogen with 49 wt \% lignin monomer yields with propanolsyringol and propanolguaiacol as main lignin products (entry 53 in Table 1). Phase separation of n-butanol and water upon cooling offered a facile and effective strategy to isolate lignin-derived phenolics (n-butanol phase) from polyols (aqueous phase).

Carbohydrates served as an inherent hydrogen donor in a bark RCF process producing hydrocarbon bio-oil in gasoline and diesel ranges and 4-ethylguaiacol [73]. RCF of vanilla seeds was used to investigate the depolymerization of naturally occurring C-lignin, which consists solely of caffeyl alcohol units; only two products (propyl- and propenyl catechol, 2018 second row in Figure 4) were gained with $21 \mathrm{wt} \%$ lignin monomer yield (entry 55 in Table 1) [74]. Selective fragmentation into hydroxycinnamic esters (methyl coumarate and methyl ferulate (Figure 4)) was reached by RCF of corncob using MCM-41 supported $\mathrm{ZnMoO}_{4}$ catalyst in methanol [75]. The effect of support, added base, and solvent was studied in the catalytic depolymerization of cork over $\mathrm{Rh} / \mathrm{C}$ catalyst: the highest bio-oil yield (43 wt \%) was reached by a 2-methyl tetrahydrofuran/water 'green' solvent mixture (entry 57 in Table 1) [76]. The reusability of $\mathrm{Ru} / \mathrm{SiC}$ compared to $\mathrm{Ru} / \mathrm{C}$ catalyst was emphasized in the RCF of apple wood to lignin-oil further converted to jet fuel aromatics and polyurethane [77]. Unsupported $\mathrm{MoS}_{2}$ catalyst was used in the RCF of corn stover and $18 \mathrm{wt} \%$ phenolic monomers yield was reached (entry 59 in Table 1) [78].

Full utilization of biomass by means of solar energy was reached in 2018 by CdS quantum dots catalyzed cleavage of the $\beta-\mathrm{O}-4$ bonds in birch into functionalized aromatics (2018 third row in Figure 4), xylose, and glucose under visible light at room temperature. The $\beta-\mathrm{O}-4$ bond in lignin is cleaved by an electron-hole coupled photoredox mechanism based on a $C_{\alpha}$ radical intermediate, in which both photogenerated electrons and holes participate in the reaction. Due to the colloidal character of the catalyst it could be easily separated and recycled [79].

\subsection{9}

A new 'lignin-first' paper in 2019 discusses RCF of birch wood with high (up to 34 wt \%) yields to monophenolic compounds (10\% propylsyringol and 9\% propenylsyringol) using Co-phen/C catalyst and formic acid or formate as a hydrogen donor (entry 61 in Table 1). The high yield was explained by transfer hydrogenolysis reactions of lignin fragments targeting the $\beta-\mathrm{O}-4^{\prime}$ bond and stabilizing reactive intermediates due to the cobalt catalyst [80]. Formic acid was also used as hydrogen source and as co-catalysts beside $\mathrm{Ni}-\mathrm{Al} / \mathrm{C}$ in another paper and a positive correlation was suggested between spillover hydrogen on the catalysts and lignin-derived phenolic monomer yields [81]. $\mathrm{Pt} / \mathrm{Al}_{2} \mathrm{O}_{3}$ not only converted birch into phenolic monomers but also catalyzed methanol reforming in methanol-water mixtures to supply hydrogen. Increased lignin monomer yield (49 wt \%, entry 63 in Table 1) was attributed to the stabilization of reactive lignin intermediates by hydrogenation of reactive bonds due to the higher hydrogen yield [82].

A proof-of-concept membrane filtration was demonstrated by Rinaldi and co-workers in 2019, for the separation and concentration of the monophenol-rich fraction (entry 64 in Table 1) from the lignin liquors (poplar, Raney Ni catalyst, isopropanol/water solvent/H-donor mixture) [83]. In a further paper, the impact of process severity (reaction temperature) was studied by the same group, using the same feedstock, catalysts, and solvent mixture in the second one [84]. Higher process temperatures led to improving overall delignification yields (up to 87\%), producing low molar mass fragments and 
preferential cleavage of hydroxyl groups in monolignol sidechains via hydrodeoxygenation, yielding oils with lower oxygen content [84].

$\mathrm{Ni} / \mathrm{C}$-catalyzed delignification of poplar resulted recalcitrance to enzymatic digestion of cellulose. Subsequent gelatinization in trifluoroacetic acid greatly enhanced rates of enzymatic digestion or maleic acid- $\mathrm{AlCl}_{3}$ catalyzed conversion to hydroxymethylfurfural (HMF) and levulinic acid (LA). These results informed a 'no carbon left behind' strategy to convert total woody biomass into lignin, cellulose, and hemicellulose value streams for the future biorefinery [85].

Two task-specific catalysts were developed for RCF: Mox C/CNT for hardwood, and Ru/CMK-3 for softwood and grass. Using Mo $\mathrm{C} / \mathrm{CNT}$ for apple wood led to a carbohydrate (both cellulose and hemicellulose) retention degree in solid product close to theoretical maximum and a delignification degree as high as $98.1 \%$ with $42 \%$ lignin monomers yield (entry 67 in Table 1) [86].

Chemodivergent hydrogenolysis of eucalyptus sawdust was carried out with Ni@ZIF-8 catalyst: phenolic compounds having either a propyl or propanol end-chain were produced under different reaction conditions. Propanol-substituted phenols (10\% propanolsyringol, 5\% propanolguaiacol) at $220{ }^{\circ} \mathrm{C}$ and 30 bar $\mathrm{H}_{2}$ within $4 \mathrm{~h}$ were identified as the major depolymerized products, while propyl-substituted phenols (24\% propylsyringol and propylguaiacol) where those at $260{ }^{\circ} \mathrm{C}$ and 30 bar $\mathrm{H}_{2}$ within 8 h (entry 68 in Table 1) [87].

A homogeneous catalytic system (binuclear Rh complex) for a "lignin-first" biorefinery in water was applied for basswood producing aromatic ketones (2\% propanonesyringol, and 1.6\% ethanonesyringol (Figure 4)) with almost complete deconstruction of lignin component under mild conditions $\left(110^{\circ} \mathrm{C}, 1\right.$ bar Ar, $24 \mathrm{~h}$, entry 69 in Table 1) [88].

\subsection{0}

The same rhodium terpyridine complexes as homogeneous catalysts were used by the same group as in 2019 [88] for redox-neutral depolymerization of poplar wood under mild conditions affording aromatic ketones as the major monomer products (entry 70 in Table 1) [89].

The integrated biorefinery concept originated from Sels et al. [42,65] was developed further by the same group in 2020 [90]. The process model integrated three catalytic steps: RCF of wood, hydroprocessing of crude monomers extract, and dealkylation of crude alkylphenol product stream. $\mathrm{Ru} / \mathrm{C}$ catalyst in methanol solvent converted birch in the first RCF step into a carbohydrate pulp amenable to bioethanol production and a lignin oil. Lignin monomers were cost-efficiently extracted from lignin oil with fossil $n$-hexane and were catalytically funneled into phenol and propylene (entry 71 in Table 1, and 2020, first row in Figure 4). A $78 \mathrm{wt} \%$ measure of birch was converted into xylochemicals [90]. An integrated techno-economic assessment of the biorefinery process that directly integrates the results of lab studies with economic costs and benefits was also developed [101]. They found that the scale of the plant, the feedstock-specific output quantities, and output prices highly determine the economic feasibility. The Sels group patented the chemocatalytic biorefinery concept [91]. Accordingly, three separate product fractions are produced in this biorefinery: (i) a lignin oil enriched with high contents of lignin-derived (mono)phenolics, (ii) essentially humin (furanic oligomers)-free hemicellulose-derived polyols, and (iii) a cellulose pulp. An example for eucalyptus sawdust is given as Entry 72 in Table 1.

Softwood lignocellulose was effectively (77-98\%) depolymerized in a mild lignin-first acidolysis process $\left(140{ }^{\circ} \mathrm{C}, 40 \mathrm{~min}\right.$, entry 73 in Table 1) using dimethyl carbonate and ethylene glycol solvents/stabilization agent producing high yield ( $9 \mathrm{wt} \%$ ) of aromatic monophenols (2020, second row in Figure 4) and preserving cellulose as evidenced by a 85\% glucose yield after enzymatic digestion [92]. The total utilization of lignin and carbohydrates in eucalyptus towards phenolics, levulinic acid, and furfural was emphasized in another paper in 2020: Pd/C catalyst in methanol solvent was used in the hydrogenolysis step, $50 \mathrm{wt} \%$ maximum phenolic monomers yield was achieved (entry 74 in Table 1) [93]. Beech wood was directly converted into lignin derived monomers ( $20 \mathrm{wt} \%$ yield) and 
dimers and holocellulose derived light hydrocarbons in the presence of a sulfided $\mathrm{NiMo} / \mathrm{Al}_{2} \mathrm{O}_{3}$ catalyst in ethanol solvent at $260^{\circ} \mathrm{C}$ (entry 75 in Table 1) [94].

Phenol was produced in a three-step process from pinewood with a $10 \mathrm{~mol} \%$ overall yield [95]. In the first step pinewood was transformed into monomeric alkylmethoxyphenols using $\mathrm{Pt} / \mathrm{C}$ catalyst in a methanol/water mixture as solvent at $230{ }^{\circ} \mathrm{C}$ and $30 \mathrm{bar}_{2}$ pressure by the selective cleavage of $\beta-\mathrm{O}-4$ lignin bonds (entry 76 in Table 1 ). Subsequently, the methoxy groups were removed by combination of $\mathrm{MoP} / \mathrm{SiO}_{2}$ and $\mathrm{H}-\mathrm{ZSM}-5$ catalysts leading to the formation of 4-alkylphenols-including 4-propylguaiacol, ethylguaiacol, and methylguaiacol—that were eventually dealkylated to phenol using H-ZSM-5 catalyst in the third step.

Zeolite-assisted fractionation of lignocellulose by preventing the recondensation reactions of aldehydes and allylic alcohols was achieved by Samec, Corma, and coworkers [96]. This prevention effect was attributed to the shape/size selectivity of protonic Beta zeolites, whose pore size limits undesired side reactions such as bimolecular condensations. In addition, mechanistic studies have pointed out that the reductive dehydration of allylic alcohols is carried out in the pores of metal-free zeolites. The highest lignin monomers yield from the organosolv pulping of birch wood was $20 \mathrm{wt} \%$, using an ethanol/water mixture at $220^{\circ} \mathrm{C}$ for two hours (entry 77 in Table 1). In parallel, furfural and ethylfurfural have been obtained as result of cellulose and hemicellulose fractions depolymerization over zeolitic acid sites.

Based on their previous kinetic studies of RCF [62,63], Román-Leshkov et al. [97] developed detailed mesoscale reaction-diffusion models for lignin-first fractionation. The models predict that mass transfer plays a governing role in solvolytic lignin extraction at the mesoscale. Lignin fragment diffusion competes with mass transfer resistance, which seems to be dominant effect when biomass particle size is over $2 \mathrm{~nm}$. It is advisable to perform such tests for catalysts evaluation when the particle size of biomass is smaller than $2 \mathrm{~nm}$, when the kinetics of the reaction is controlled by the diffusion of lignin fractions.

New concepts for lignin-first processes were introduced in 2020. Lignin-first integrated hydrothermal treatment [98], using an ionic liquid for lignin-first fractionation [99], and fractionation of wood with a $\gamma$-valerolactone consisting solvent system [100], was suggested. We do not consider the first two procedures as strictly regarded lignin-first processes as either a catalyst was not used [98], or reductive conditions were not applied $[98,99]$. The last procedure is remarkable, as a continuous operation was used to depolymerize maple wood lignin in a stirred reactor, which means continuous feeding of thermally pretreated lignin solution into the reactor and the products were collected at the outlet in a sample vial at $30 \mathrm{~min}$ intervals [100].

\section{Summary}

Early studies (1940-1986) on wood digestion or conversion using a catalyst were mainly focused on the elucidation of the chemical structure of lignin. The 4-n-propylphenol nature of the lignin monomers was confirmed [5]. With environmental concerns and increasing need to shift away from the dependence on fossil resources, interest in biomass as a sustainable feedstock has been resurgent, and lignocellulose has been identified as an important feedstock because it does not compete with the food supply. Innovative approaches, mainly related to efficient valorization of the cellulose platform have been introduced, together with the definition of top value-added platform chemicals. However, research in lignin has lagged behind due to its recalcitrant structure and it was only predominantly after 2010 that lignin conversion gained momentum and many fundamental works have been published, wherein significant progress has been made.

Notable advances in the one-pot full conversion of lignocellulose include the use of supercritical methanol as hydrogen source for the highly efficient conversion of lignocellulose to aliphatic small molecules in 2010 and 2011. The importance of supressing char formation has been recognized here. Later, interesting works to provide highly useful molecules in a one-pot, one-step process were the direct production of light naphtha (n-hexane, n-pentane, cyclohexane, and methylcyclopentane) by 
the Sels group in 2015 [42], which was developed further in 2018 [65] and 2020 [83] producing phenol and propylene. Liquid alkylcyclohexanes and polyols over $\mathrm{Ru} / \mathrm{C}$ catalysts [70], and propylphenols, $\mathrm{C}_{5}-\mathrm{C}_{6}$ ketones, and furans over sulfided $\mathrm{NiMo} / \mathrm{Al}_{2} \mathrm{O}_{3}$ catalysts [94] were formed in other one-pot one-step processes.

The concept of stabilization of reactive intermediates emerged in many different aspects in the field. One of the elegant examples of stabilization was introduced by Luterbacher et al. who described the role of formaldehyde and other carbonyl compounds in the protection of the native $\beta-\mathrm{O}-4$ moiety during extraction, and thereby achieved much higher yields of desired monoaromatic products [6]. Trapping reactive intermediates originating from acid treatment after depolymerization in the form of acetals has also resulted in the suppression of recondensation and increased monomer yield from lignin. This approach has shown success on lignocellulose both in toluene/methanol mixtures [47], or more recently in dimethyl carbonate as solvent [84].

Undoubtedly, reductive catalytic fractionation (RCF) introduced during 2014-2015 by three research groups [39-41], has emerged as highly efficient method (also relying on stabilization) for lignocellulose valorization. Much research has been done regarding catalyst development, the role of additives, and types of hydrogen donors as well as reaction setup. For example using $\mathrm{Zn}-\mathrm{Pd} / \mathrm{C}$ bimetallic and $\mathrm{Ru} / \mathrm{C}$ catalysts resulted in higher than $50 \%$ lignin monomers yield [40,41], isopropanol solvent ensured the source of hydrogen [39], and the direct production of light naphtha Ref. [42] became possible. This method has matured over the years towards achieving integrated biorefinery approaches in 2018, reaching the complete valorization of all lignocellulose constituents. For example, value-added products (propanolguaiacol and aliphatic alcohols) were produced in a model biorefinery with complete lignocellulose conversion. Importantly, these were further converted to a plethora of value-added building blocks with focus on amines [64]. The cellulose fraction was fully converted, in supercritical methanol, allowing for catalyst recycling. The aliphatic alcohols obtained in this step were coupled with cyclopentanone and subsequently converted to hydrocarbons, with target of jet-fuel range cyclic alkanes. Furthermore, an elegant liquid phase cellulose-to-naphtha technology was developed [65]. A deep converting 'lignin-first' biorefinery concept meaning gasoline and kerosene/diesel production was introduced [66]. Liquid alkylcyclohexanes, arenes, polyols, and furfural derivatives were produced $[70,71]$. The latest novel results were carried out using new catalysts $[80,87,88]$ and by developing task-specific catalysts for hardwood and softwood [86], chemodivergent hydrogenolysis (for propyl- or propanol-methoxyphenol production) [87], membrane filtration [83], and applying new solvents/stabilization agent (dimethyl carbonate) [92]. The first integrated techno-economic assessment of a biorefinery process revealed that using only waste wood as feedstock can make the investment profitable [101].

In all the RCF systems, where the lignin fraction is valorized 'first', the celluloses will remain mixed with the heterogeneous catalyst, which means that the catalyst recycling issue needs to be addressed and many creative solutions have been already found. Possible solutions for catalyst separation were developed using a magnetic catalyst [39], membrane filtration [83], or embedding the metal function in a cage [4]. Adding a second catalytic step that converts all process residues was also developed, which liberated the catalyst for re-use [64].

\section{Future Perspectives and Challenges}

Several achievements have already been reached in 'lignin-first' process technology in recent years: noble-metal containing catalysts were replaced by more sustainable metals, or other catalysts; hydrogen was produced self-sufficiently from the pulp or solvent, and a good level of uniformity and chemodivergency of the products using mild conditions and appropriate (task-specific) catalysts has been reached, pointing toward exciting possibilities for ultimately converting total woody biomass into value-added products (as per the 'no carbon left behind' strategy). Notably, there were examples for the integration of biorefinery into petrorefinery processes, and the direct usage of lignin oil as a 
sulphur-free diesel-soluble liquid fuel. Semi-continuous flow-through systems have been established with good efficiency.

Future work will undoubtedly focus on several directions such as replacing batch reactors with really continuous flow-through systems and development of RCF processes applicable to crude biomass and lignocellulosic waste streams (e.g., bark). Effective removal of the catalyst from the pulp to enable subsequent enzymatic or catalytic treatment of the (hemi)cellulose fraction and improving recyclability of the catalysts will be essential to move toward real upscaling efforts, where in addition, the choices of solvent will be very important.

RCF enables to derive more value from lignin by increasing the yield and selectivity of desired aromatic monomers, which enables the more efficient production of well-defined products from lignin, thereby influencing the overall economic feasibility of lignocellulosic biorefineries. In the future, focus will also shift toward establishing downstream processing strategies for all lignocellulose constituents, and the diversification of the product portfolio accessible from lignocellulosic biorefineries.

Author Contributions: T.I.K. wrote the manuscript, B.F. produced the figures, A.P. included relevant patents, K.B. contributed to figures and text, all authors commented the manuscript. All authors have read and agreed to the published version of the manuscript.

Funding: This research received no external funding.

Acknowledgments: The authors acknowledge the networking support by the COST Action CA17128-Establishment of a Pan-European Network on the Sustainable Valorization of Lignin.

Conflicts of Interest: The authors declare no conflict of interest.

\section{References}

1. Ragauskas, A.J.; Beckham, G.T.; Biddy, M.J.; Chandra, R.; Chen, F.; Davis, M.F.; Davison, B.F.; Dixon, R.A.; Gilna, P.; Keller, M.; et al. Lignin valorization: Improving lignin processing in the biorefinery. Science 2014, 344, 1246843. [CrossRef] [PubMed]

2. Zakzeski, J.; Bruijnincx, P.C.A.; Jongerius, A.L.; Weckhuysen, B.M. The catalytic valorization of lignin for the production of renewable chemicals. Chem. Rev. 2010, 110, 3552-3599. [CrossRef] [PubMed]

3. Sun, Z.; Fridrich, B.; de Santi, A.; Elangovan, S.; Barta, K. Bright side of lignin depolymerization: Toward new platform chemicals. Chem. Rev. 2018, 118, 614-678. [CrossRef] [PubMed]

4. Van den Bosch, S.; Renders, T.; Kennis, S.; Koelewijn, S.-F.; Van den Bossche, G.; Vangeel, T.; Deneyer, A.; Depuydt, D.; Courtin, C.M.; Thevelein, J.M.; et al. Integrating lignin valorization and bio-ethanol production: On the role of $\mathrm{Ni}-\mathrm{Al}_{2} \mathrm{O}_{3}$ catalyst pellets during lignin-first fractionation. Green Chem. 2017, 19, 3313-3326. [CrossRef]

5. Galkin, M.V.; Samec, J.S.M. Lignin valorization through catalytic lignocellulose fractionation: A fundamental platform for the future biorefinery. ChemSusChem 2016, 9, 1544-1558. [CrossRef] [PubMed]

6. Shuai, L.; Amiri, M.T.; Questell-Santiago, Y.M.; Héroguel, F.; Li, Y.; Kim, H.; Meilan, R.; Chapple, C.; Ralph, J.; Luterbacher, J.S. Formaldehyde stabilization facilitates lignin monomer production during biomass depolymerization. Science 2016, 354, 329-333. [CrossRef]

7. Xu, C.; Arancon, R.A.D.; Labidi, J.; Luque, R. Lignin depolymerisation strategies: Towards valuable chemicals and fuels. Chem. Soc. Rev. 2014, 43, 7485-7500. [CrossRef]

8. Kumar, C.R.; Anand, N.; Kloekhorst, A.; Cannilla, C.; Bonura, G.; Frusteri, F.; Barta, K.; Heeres, H.J. Solvent free depolymerization of kraft lignin to alkyl-phenolics using supported NiMo and CoMo catalysts. Green Chem. 2015, 17, 4921-4930. [CrossRef]

9. Narani, A.; Chowdari, R.K.; Cannilla, C.; Bonura, G.; Frusteri, F.; Heeres, H.J.; Barta, K. Efficient catalytic hydrotreatment of Kraft lignin to alkylphenolics using supported NiW and NiMo catalysts in supercritical methanol. Green Chem. 2015, 17, 5046-5057. [CrossRef]

10. Rahimi, A.; Ulbrich, A.; Coon, J.J.; Stahl, S.S. Formic-acid-induced depolymerization of oxidized lignin to aromatics. Nature 2014, 515, 249-252. [CrossRef]

11. Zhao, C.; Xie, S.; Pu, Y.; Zhang, R.; Huang, F.; Ragauskas, A.J.; Yuan, J.S. Synergistic enzymatic and microbial lignin conversion. Green Chem. 2016, 18, 1306-1312. [CrossRef] 
12. Luo, H.; Abu-Omar, M.M. Chemicals from lignin. In Encyclopedia of Sustainable Technologies; Abraham, M.A., Ed.; Elsevier: Amsterdam, The Netherlands, 2017; pp. 573-585. ISBN 9780128046777.

13. Van den Bosch, S.; Koelewijn, S.-F.; Renders, T.; Van den Bossche, G.; Vangeel, T.; Schutyser, W.; Sels, B.F. Catalytic strategies towards lignin-derived chemicals. Top. Curr. Chem. 2018, 376, 36. [CrossRef] [PubMed]

14. Rinaldi, R.; Jastrzebski, R.; Clough, M.T.; Ralph, J.; Kennema, M.; Bruijnincx, P.C.A.; Weckhuysen, B.M. Paving the way for lignin valorisation: Recent advances in bioengineering, biorefining and catalysis. Angew. Chem. Int. Ed. 2016, 55, 8164-8215. [CrossRef] [PubMed]

15. Renders, T.; Van den Bosch, S.; Koelewijn, S.-F.; Schutyser, W.; Sels, B.F. Lignin-first biomass fractionation: The advent of active stabilisation strategies. Energy Environ. Sci. 2017, 10, 1551-1557. [CrossRef]

16. Schutyser, W.; Renders, T.; Van den Bosch, S.; Koelewijn, S.-F.; Beckham, G.T.; Sels, B.F. Chemicals from lignin: An interplay of lignocellulose fractionation, depolymerisation, and upgrading. Chem. Soc. Rev. 2018, 47, 852-908. [CrossRef]

17. Renders, T.; Van den Bossche, G.; Vangeel, T.; Van Aelst, K.; Sels, B. Reductive catalytic fractionation: State of the art of the lignin-first biorefinery. Curr. Opin. Biotechnol. 2019, 56, 193-201. [CrossRef]

18. Ha, J.-M.; Hwang, K.-R.; Kim, Y.-M.; Jae, J.; Kim, K.H.; Lee, H.W.; Kim, J.-Y.; Park, Y.-K. Recent progress in the thermal and catalytic conversion of lignin. Renew. Sustain. Energy Rev. 2019, 111, 422-441. [CrossRef]

19. Song, Y. Lignin valorization via reductive depolymerization. In Chemical Catalysts For Biomass Upgrading; Crocker, M., Santillan-Jimenez, E., Eds.; Wiley: Weinheim, Germany, 2020; pp. 395-438. [CrossRef]

20. Paone, E.; Tabanelli, T.; Mauriello, F. The rise of lignin biorefinery. Curr. Opin. Green Sustain. Chem. 2020, 24, 1-6. [CrossRef]

21. Ferrini, P.; Rezende, C.A.; Rinaldi, R. Catalytic upstream biorefining through hydrogen transfer reactions: Understanding the process from the pulp perspective. ChemSusChem 2016, 9, 3171-3180. [CrossRef]

22. Godard, H.P.; McCarthy, J.L.; Hibbert, H. Hydrogenation of wood. J. Am. Chem. Soc. 1940, 62, 988. [CrossRef]

23. Godard, H.P.; McCarthy, J.L.; Hibbert, H. Studies on lignin and related compounds. LXII. high pressure hydrogenation of wood using copper chromite catalyst (part 1). J. Am. Chem. Soc. 1941, 63, 3061-3066. [CrossRef]

24. Bower, J.R.; Cooke, L.M.; Hibbert, H. Studies on lignin and related compounds. LXX. hydrogenolysis and hydrogenation of maple wood. J. Am. Chem. Soc. 1943, 65, 1192-1195. [CrossRef]

25. Pepper, J.M.; Hibbert, H. Studies on lignin and related compounds. LXXXVII. high pressure hydrogenation of maple wood. J. Am. Chem. Soc. 1948, 70, 67-71. [CrossRef] [PubMed]

26. Pepper, J.M.; Steck, W. The effect of time and temperature on the hydrogenation of aspen lignin. Can. J. Chem. 1963, 41, 2867-2875. [CrossRef]

27. Pepper, J.M.; Steck, W.F.; Swoboda, R.; Karapally, J.C. Hydrogenation of lignin using nickel and palladium catalysts. Lignin Struct. React. 1966, 238-248. [CrossRef]

28. Pepper, J.M.; Lee, Y.W. Lignin and related compounds. I. A comparative study of catalysts for lignin hydrogenolysis. Can. J. Chem. 1969, 47, 723-727. [CrossRef]

29. Pepper, J.M.; Lee, Y.W. Lignin and related compounds. II. studies using ruthenium and raney nickel as catalysts for lignin hydrogenolysis. Can. J. Chem. 1970, 48, 477-479. [CrossRef]

30. Pepper, J.M.; Fleming, R.W. Lignin and related compounds. V. The hydrogenolysis of aspen wood lignin using rhodium-on-charcoal as catalyst. Can. J. Chem. 1978, 56, 896-898. [CrossRef]

31. Pepper, J.M.; Supathna, P. Lignin and related compounds. VI. A study of variables affecting the hydrogenolysis of spruce wood lignin using a rhodium-on-charcoal catalyst. Can. J. Chem. 1978, 56, 899-902. [CrossRef]

32. Pepper, J.M.; Rahman, M.D. Lignin and related compounds. XI: Selective degradation of aspen poplar lignin by catalytic hydrogenolysis. Cellul. Chem. Technol. 1987, 21, 233-239.

33. Kaplunova, T.S.; Abduazimov, K.A.; Pulatov, B.K.; Ikramutdinova, M.T.; Abidova, M.F. Hydrogenolysis of Rice Husk Lignin. Chem. Nat. Compd. 1993, 29, 530-532. [CrossRef]

34. Yan, N.; Zhao, C.; Dyson, P.J.; Wang, C.; Liu, L.T.; Kou, Y. Selective degradation of wood lignin over noble-metal catalysts in a two-step process. ChemSusChem 2008, 1, 626-629. [CrossRef] [PubMed]

35. Torr, K.M.; van de Pas, D.J.; Cazeils, E.; Suckling, I.D. Mild hydrogenolysis of in-situ and isolated pinus radiata lignins. Bioresour. Technol. 2011, 102, 7608-7611. [CrossRef]

36. Li, C.; Zheng, M.; Wang, A.; Zhang, T. One-pot catalytic hydrocracking of raw woody biomass into chemicals over supported carbide catalysts: Simultaneous conversion of cellulose, hemicellulose and lignin. Energy Environ. Sci. 2012, 5, 6383-6390. [CrossRef] 
37. Song, Q.; Wang, F.; Cai, J.; Wang, Y.; Zhang, J.; Yu, W.; Xu, J. Lignin depolymerization (LDP) in alcohol over nickel-based catalysts via a fragmentation-hydrogenolysis process. Energy Environ. Sci. 2013, 6, 994-1007. [CrossRef]

38. Galkin, M.V.; Samec, J.S.M. Selective route to 2-propenyl aryls directly from wood by a tandem organosolv and palladium-catalysed transfer hydrogenolysis. ChemSusChem 2014, 7, 2154-2158. [CrossRef] [PubMed]

39. Ferrini, P.; Rinaldi, R. Catalytic biorefining of plant biomass to non-pyrolytic lignin bio-oil and carbohydrates through hydrogen transfer reactions. Angew. Chem. Int. Ed. 2014, 53, 8634-8639. [CrossRef]

40. Parsell, T.; Yohe, S.; Degenstein, J.; Jarrell, T.; Klein, I.; Gencer, E.; Hewetson, B.; Hurt, M.; Kim, J.I.; Choudhari, H.; et al. A synergistic biorefinery based on catalytic conversion of lignin prior to cellulose starting from lignocellulosic biomass. Green Chem. 2015, 17, 1492-1499. [CrossRef]

41. Van den Bosch, S.; Schutyser, W.; Vanholme, R.; Driessen, T.; Koelewijn, S.-F.; Renders, T.; De Meester, B.; Huijgen, W.J.J.; Dehaen, W.; Courtin, C.M.; et al. Reductive lignocellulose fractionation into soluble lignin-derived phenolic monomers and dimers and processable carbohydrate pulps. Energy Environ. Sci. 2015, 8, 1748-1763. [CrossRef]

42. Dusselier, M.J.; Op De Beeck, B.; Sels, B.F. Biphasic Solvent Catalytic Process for the Direct Production of Light Naphta from Carbohydrate-Containing Feedstock. Patent 10,407,623, 10 September 2019.

43. Liu, Y.; Chen, L.; Wang, T.; Zhang, Q.; Wang, C.; Yan, J.; Ma, L. One-pot catalytic conversion of raw lignocellulosic biomass into gasoline alkanes and chemicals over $\mathrm{LiTaMoO}_{6}$ and $\mathrm{Ru} / \mathrm{C}$ in aqueous phosphoric acid. ACS Sustain. Chem. Eng. 2015, 3, 1745-1755. [CrossRef]

44. Van den Bosch, S.; Schutyser, W.; Koelewijn, S.-F.; Renders, T.; Courtin, C.M.; Sels, B.F. Tuning the lignin oil $\mathrm{OH}$-content with $\mathrm{Ru}$ and Pd catalysts during lignin hydrogenolysis on birch wood. Chem. Commun. 2015, 51, 13158-13161. [CrossRef] [PubMed]

45. Schutyser, W.; Van den Bosch, S.; Renders, T.; De Boe, T.; Koelewijn, S.-F.; Dewaele, A.; Ennaert, T.; Verkinderen, O.; Goderis, B.; Courtin, C.M.; et al. Influence of bio-based solvents on the catalytic reductive fractionation of birch wood. Green Chem. 2015, 17, 5035-5045. [CrossRef]

46. Klein, I.; Saha, B.; Abu-Omar, M.M. Lignin depolymerization over Ni/C catalyst in methanol, a continuation: Effect of substrate and catalyst loading. Catal. Sci. Technol. 2015, 5, 3242-3245. [CrossRef]

47. Kaiho, A.; Kogo, M.; Sakai, R.; Saito, K.; Watanabe, T. In situ trapping of enol intermediates with alcohol during acid-catalysed de-polymerisation of lignin in a nonpolar solvent. Green Chem. 2015, 17, 2780-2783. [CrossRef]

48. Galkin, M.V.; Smit, A.T.; Subbotina, E.; Artemenko, K.A.; Bergquist, J.; Huijgen, W.J.J.; Samec, J.S.M. Hydrogen-free catalytic fractionation of woody biomass. ChemSusChem 2016, 9, 3280-3287. [CrossRef]

49. Klein, I.; Marcum, C.; Kenttämaa, H.; Abu-Omar, M.M. Mechanistic investigation of the Zn/Pd/C catalyzed cleavage and hydrodeoxygenation of lignin. Green Chem. 2016, 18, 2399-2405. [CrossRef]

50. Luo, H.; Klein, I.M.; Jiang, Y.; Zhu, H.; Liu, B.; Kenttämaa, H.I.; Abu-Omar, M.M. Total utilization of miscanthus biomass, lignin and carbohydrates, using earth abundant nickel catalyst. ACS Sustain. Chem. Eng. 2016, 4, 2316-2322. [CrossRef]

51. Jastrzebski, R.; Constant, S.; Lancefield, C.S.; Westwood, N.J.; Weckhuysen, B.M.; Bruijnincx, P.C.A. Tandem catalytic depolymerization of lignin by water-tolerant lewis acids and rhodium complexes. ChemSusChem 2016, 9, 2074-2079. [CrossRef]

52. Huang, X.; Zhu, J.; Korányi, T.I.; Boot, M.D.; Hensen, E.J.M. Effective release of lignin fragments from lignocellulose by lewis acid metal triflates in the lignin-first approach. ChemSusChem 2016, 9, 3262-3267. [CrossRef]

53. Chen, J.; Lu, F.; Si, X.; Nie, X.; Chen, J.; Lu, R.; Xu, J. High yield production of natural phenolic alcohols from woody biomass using a nickel-based catalyst. ChemSusChem 2016, 9, 3353-3360. [CrossRef]

54. Anderson, E.M.; Katahira, R.; Reed, M.; Resch, M.G.; Karp, E.M.; Beckham, G.T.; Román-Leshkov, Y. Reductive catalytic fractionation of corn stover lignin. ACS Sustain. Chem. Eng. 2016, 4, 6940-6950. [CrossRef]

55. Renders, T.; Schutyser, W.; Van Den Bosch, S.; Koelewijn, S.F.; Vangeel, T.; Courtin, C.M.; Sels, B.F. Influence of acidic $\left(\mathrm{H}_{3} \mathrm{PO}_{4}\right)$ and alkaline $(\mathrm{NaOH})$ additives on the catalytic reductive fractionation of lignocellulose. ACS Catal. 2016, 6, 2055-2066. [CrossRef]

56. Renders, T.; Van den Bosch, S.; Vangeel, T.; Ennaert, T.; Koelewijn, S.-F.; Van den Bossche, G.; Courtin, C.M.; Schutyser, W.; Sels, B.F. Synergetic effects of alcohol/water mixing on the catalytic reductive fractionation of poplar wood. ACS Sustain. Chem. Eng. 2016, 4, 6894-6904. [CrossRef] 
57. Huang, X.; Morales Gonzalez, O.M.; Zhu, J.; Korányi, T.I.; Boot, M.D.; Hensen, E.J.M. Reductive fractionation of woody biomass into lignin monomers and cellulose by tandem metal triflate and Pd/C catalysis. Green Chem. 2017, 19, 175-187. [CrossRef]

58. Huang, X.; Ouyang, X.; Hendriks, B.; Gonzalez, O.M.M.; Zhu, J.; Korányi, T.I.; Boot, M.; Hensen, E.J.M. Selective production of mono-aromatics from lignocellulose over $\mathrm{Pd} / \mathrm{C}$ catalyst: The influence of acid co-catalysts. Faraday Discuss. 2017, 202, 141-156. [CrossRef] [PubMed]

59. Zhai, Y.; Li, C.; Xu, G.; Ma, Y.; Liu, X.; Zhang, Y. Depolymerization of lignin via a non-precious Ni-Fe alloy catalyst supported on activated carbon. Green Chem. 2017, 19, 1895-1903. [CrossRef]

60. van de Pas, D.J.; Torr, K.M. Biobased epoxy resins from deconstructed native softwood lignin. Biomacromolecules 2017, 18, 2640-2648. [CrossRef]

61. Kumaniaev, I.; Subbotina, E.; Sävmarker, J.; Larhed, M.; Galkin, M.V.; Samec, J. Lignin depolymerization to monophenolic compounds in a flow-through system. Green Chem. 2017, 19, 5767-5771. [CrossRef]

62. Anderson, E.M.; Stone, M.L.; Katahira, R.; Reed, M.; Beckham, G.T.; Román-Leshkov, Y. Flowthrough reductive catalytic fractionation of biomass. Joule. 2017, 1, 613-622. [CrossRef]

63. Anderson, E.M.; Stone, M.L.; Hülsey, M.J.; Beckham, G.T.; Román-Leshkov, Y. Kinetic studies of lignin solvolysis and reduction by reductive catalytic fractionation decoupled in flow-through reactors. ACS Sustain. Chem. Eng. 2018, 6, 7951-7959. [CrossRef]

64. Sun, Z.; Bottari, G.; Afanasenko, A.; Stuart, M.C.A.; Deuss, P.J.; Fridrich, B.; Barta, K. Complete lignocellulose conversion with integrated catalyst recycling yielding valuable aromatics and fuels. Nat. Catal. 2018, 1, 82-92. [CrossRef]

65. Deneyer, A.; Peeters, E.; Renders, T.; Van den Bosch, S.; Van Oeckel, N.; Ennaert, T.; Szarvas, T.; Korányi, T.I.; Dusselier, M.; Sels, B.F. Direct upstream integration of biogasoline production into current light straight run naphtha petrorefinery processes. Nat. Energy 2018, 3, 969-977. [CrossRef]

66. Cao, Z.; Dierks, M.; Clough, M.T.; de Castro, I.B.D.; Rinaldi, R. A convergent approach for a deep converting lignin-first biorefinery rendering high-energy-density drop-in fuels. Joule. 2018, 2, 1118-1133. [CrossRef] [PubMed]

67. Graça, I.; Woodward, R.T.; Kennema, M.; Rinaldi, R. Formation and fate of carboxylic acids in the lignin-first biorefining of lignocellulose via h-transfer catalyzed by raney Ni. ACS Sustain. Chem. Eng. 2018, 6, 13408-13419. [CrossRef]

68. Sagues, W.J.; Bao, H.; Nemenyi, J.L.; Tong, Z. A lignin-first approach to biorefining: Utilizing fenton's reagent and supercritical ethanol for the production of phenolics and sugars. ACS Sustain. Chem. Eng. 2018, 6, 4958-4965. [CrossRef]

69. Ouyang, X.; Huang, X.; Hendriks, B.M.S.; Boot, M.D.; Hensen, E.J.M. Coupling organosolv fractionation and reductive depolymerization of woody biomass in a two-step catalytic process. Green Chem. 2018, 20, 2308-2319. [CrossRef]

70. Li, X.; Guo, T.; Xia, Q.; Liu, X.; Wang, Y. One-pot catalytic transformation of lignocellulosic biomass into alkylcyclohexanes and polyols. ACS Sustain. Chem. Eng. 2018, 6, 4390-4399. [CrossRef]

71. Guo, T.; Li, X.; Liu, X.; Guo, Y.; Wang, Y. Catalytic transformation of lignocellulosic biomass into arenes, 5-hydroxymethylfurfural, and furfural. ChemSusChem 2018, 11, 2758-2765. [CrossRef]

72. Renders, T.; Cooreman, E.; Van den Bosch, S.; Schutyser, W.; Koelewijn, S.-F.; Vangeel, T.; Deneyer, A.; Van den Bossche, G.; Courtin, C.M.; Sels, B.F. Catalytic lignocellulose biorefining in n-butanol/water: A one-pot approach toward phenolics, polyols, and cellulose. Green Chem. 2018, 20, 4607-4619. [CrossRef]

73. Kumaniaev, I.; Samec, J.S.M. Valorization of quercus suber bark toward hydrocarbon bio-oil and 4-ethylguaiacol. ACS Sustain. Chem. Eng. 2018, 6, 5737-5742. [CrossRef]

74. Stone, M.L.; Anderson, E.M.; Meek, K.M.; Reed, M.; Katahira, R.; Chen, F.; Dixon, R.A.; Beckham, G.T.; Román-Leshkov, Y. Reductive catalytic fractionation of c-lignin. ACS Sustain. Chem. Eng. 2018, 6, 11211-11218. [CrossRef]

75. Wang, S.; Gao, W.; Li, H.; Xiao, L.-P.; Sun, R.-C.; Song, G. Selective fragmentation of biorefinery corncob lignin into p-hydroxycinnamic esters with a supported $\mathrm{ZnMoO}_{4}$ catalyst. ChemSusChem 2018, 11, 2114-2123. [CrossRef] [PubMed]

76. McCallum, C.S.; Strachan, N.; Bennett, S.C.; Forsythe, W.G.; Garrett, M.D.; Hardacre, C.; Morgan, K.; Sheldrake, G.N. Catalytic depolymerisation of suberin rich biomass with precious metal catalysts. Green Chem. 2018, 20, 2702-2705. [CrossRef] 
77. Huang, Y.; Duan, Y.; Qiu, S.; Wang, M.; Ju, C.; Cao, H.; Fang, Y.; Tan, T. Lignin-first biorefinery: A reusable catalyst for lignin depolymerization and application of lignin oil to jet fuel aromatics and polyurethane feedstock. Sustain. Energy Fuels 2018, 2, 637-647. [CrossRef]

78. Li, S.; Li, W.; Zhang, Q.; Shu, R.; Wang, H.; Xin, H.; Ma, L. Lignin-first depolymerization of native corn stover with an unsupported $\mathrm{MoS}_{2}$ catalyst. Rsc Adv. 2018, 8, 1361-1370. [CrossRef]

79. Wu, X.; Fan, X.; Xie, S.; Lin, J.; Cheng, J.; Zhang, Q.; Chen, L.; Wang, Y. Solar energy-driven lignin-first approach to full utilization of lignocellulosic biomass under mild conditions. Nat. Catal. 2018, 1, 772-780. [CrossRef]

80. Rautiainen, S.; Di Francesco, D.; Katea, S.; Westin, G.; Tungasita, D.; Samec, J. Lignin valorization by cobalt-catalyzed fractionation of lignocellulose to yield monophenolic compounds. ChemSusChem 2019, 12, 404-408. [CrossRef]

81. Park, J.; Riaz, A.; Verma, D.; Lee, H.J.; Woo, H.M.; Kim, J. Fractionation of lignocellulosic biomass over core-shell Ni-alumina catalysts with formic acid as a co-catalyst and hydrogen source. ChemSusChem 2019, 12, 1743-1762. [CrossRef]

82. Ouyang, X.; Huang, X.; Zhu, J.; Boot, M.D.; Hensen, E.J.M. Catalytic conversion of lignin in woody biomass into phenolic monomers in methanol/water mixtures without external hydrogen. ACS Sustain. Chem. Eng. 2019, 7, 13764-13773. [CrossRef]

83. Sultan, Z.; Graça, I.; Li, Y.; Lima, S.; Peeva, L.G.; Kim, D.; Ebrahim, M.A.A.; Rinaldi, R.; Livingston, A. Membrane fractionation of liquors from lignin-first biorefining. ChemSusChem 2019, 12, 1203-1212. [CrossRef]

84. Rinaldi, R.; Woodward, R.T.; Ferrini, P.; Riverac, H.J.E. Lignin-first biorefining of lignocellulose: The impact of process severity on the uniformity of lignin oil composition. J. Braz. Chem. Soc. 2019, 30, 479-491. [CrossRef]

85. Yang, H.; Zhang, X.; Luo, H.; Liu, B.; Shiga, T.M.; Li, X.; Kim, J.I.; Rubinelli, P.; Overton, J.C.; Subramanyam, V.; et al. Overcoming cellulose recalcitrance in woody biomass for the lignin-first biorefinery. Biotechnol. Biofuels 2019, 12, 171. [CrossRef] [PubMed]

86. Qiu, S.; Guo, X.; Huang, Y.; Fang, Y.; Tan, T. Task-specific catalyst development for lignin-first biorefinery toward hemicellulose retention or feedstock extension. ChemSusChem 2019, 12, 944-954. [CrossRef]

87. Liu, X.; Li, H.; Xiao, L.-P.; Sun, R.-C.; Song, G. Chemodivergent hydrogenolysis of eucalyptus lignin with Ni@ZIF-8 catalyst. Green Chem. 2019, 21, 1498-1504. [CrossRef]

88. Liu, Y.; Li, C.; Miao, W.; Tang, W.; Xue, D.; Li, C.; Zhang, B.; Xiao, J.; Wang, A.; Zhang, T.; et al. Mild redox-neutral depolymerization of lignin with a binuclear rh complex in water. ACS Catal. 2019, 9, 4441-4447. [CrossRef]

89. Liu, Y.; Li, C.; Miao, W.; Tang, W.; Xue, D.; Xiao, J.; Zhang, T.; Wang, C. Rhodium-terpyridine catalyzed redox-neutral depolymerization of lignin in water. Green Chem. 2020, 22, 33-38. [CrossRef]

90. Liao, Y.; Koelewijn, S.-F.; Van den Bossche, G.; Van Aelst, J.; Van den Bosch, S.; Renders, T.; Navare, K.; Nicolaï, T.; Van Aelst, K.; Maesen, M.; et al. A sustainable wood biorefinery for low-carbon footprint chemicals production. Science 2020, 367, 1385-1390. [CrossRef]

91. Sels, B.; Renders, T.; Cooreman, E.; Van den Bosch, S. Fractionation and depolymerisation of lignocellulosic material. International Application No. PCT/EP2019/066887, 2 January 2020.

92. De Santi, A.; Galkin, M.V.; Lahive, C.W.; Deuss, P.J.; Barta, K. Lignin-first fractionation of softwood lignocellulose using a mild dimethyl carbonate and ethylene glycol organosolv process. ChemSusChem 2020, in press. [CrossRef]

93. Chen, X.; Zhang, K.; Xiao, L.-P.; Sun, R.-C.; Song, G. Total utilization of lignin and carbohydrates in eucalyptus grandis: An integrated biorefinery strategy towards phenolics, levulinic acid, and furfural. Biotechnol. Biofuels 2020, 13, 1-10. [CrossRef]

94. Parto, S.G.; Jørgensen, E.K.; Christensen, J.M.; Pedersen, L.S.; Larsen, D.B.; Duus, J.Ø.; Jensen, A.D. Solvent assisted catalytic conversion of beech wood and organosolv lignin over $\mathrm{NiMo} / \gamma-\mathrm{Al}_{2} \mathrm{O}_{3}$. Sustain. Energy Fuels 2020, 4, 1844-1854. [CrossRef]

95. Ouyang, X.; Huang, X.; Boot, M.D.; Hensen, E.J.M. Efficient conversion of pine wood lignin to phenol. Chemsuschem 2020, 13, 1705-1709. [CrossRef] [PubMed]

96. Subbotina, E.; Velty, A.; Samec, J.S.M.; Corma, A. Zeolite-assisted lignin-first fractionation of lignocellulose: Overcoming lignin recondensation via shape-selective catalysis. ChemSusChem 2020, in press. [CrossRef] [PubMed] 
97. Thornburg, N.E.; Pecha, M.B.; Brandner, D.G.; Reed, M.L.; Vermaas, J.V.; Michener, W.E.; Katahira, R.; Vinzant, T.B.; Foust, T.D.; Donohoe, B.S.; et al. Mesoscale reaction-diffusion phenomena governing lignin-first biomass fractionation. ChemSusChem 2020, in press. [CrossRef]

98. Lourencon, T.V.; Greca, L.G.; Tarasov, D.; Borrega, M.; Tamminen, T.; Rojas, O.J.; Balakshin, M.Y. Lignin-first integrated hydrothermal treatment (HTT) and synthesis of low-cost biorefinery particles. ACS Sustain. Chem. Eng. 2020, 8, 1230-1239. [CrossRef]

99. Xu, J.; Dai, L.; Gui, Y.; Yuan, L.; Zhang, C.; Lei, Y. Synergistic benefits from a lignin-first biorefinery of poplar via coupling acesulfamate ionic liquid followed by mild alkaline extraction. Bioresour. Technol. 2020, 303, 122888. [CrossRef] [PubMed]

100. Nandiwale, K.Y.; Danby, A.M.; Ramanathan, A.; Chaudhari, R.V.; Motagamwala, A.H.; Dumesic, J.A.; Subramaniam, B. Enhanced acid-catalyzed lignin depolymerization in a continuous reactor with stable activity. ACS Sustain. Chem. Eng. 2020, 8, 4096-4106. [CrossRef]

101. Tschulkow, M.; Compernolle, T.; Van den Bosch, S.; Van Aelst, J.; Storms, I.; Van Dael, M.; Van den Bossche, G.; Sels, B.; Van Passel, S. Integrated techno-economic assessment of a biorefinery process: The high-end valorization of the lignocellulosic fraction in wood streams. J. Clean. Prod. 2020, 266, 122022. [CrossRef]

(C) 2020 by the authors. Licensee MDPI, Basel, Switzerland. This article is an open access article distributed under the terms and conditions of the Creative Commons Attribution (CC BY) license (http://creativecommons.org/licenses/by/4.0/). 